American Journal of Pharmacology and Toxicology 4 (3):56-74, 2009

ISSN 1557-4962

(C) 2008 Science Publications

\title{
Antioxidant Research in Asia in the Period from 2000-2008
}

\author{
${ }^{1,2}$ R.R. Hafidh, ${ }^{1}$ A.S. Abdulamir, ${ }^{1,2}$ F. Abu Bakar, ${ }^{1,2}$ F. Abas, \\ ${ }^{3}$ F. Jahanshiri and ${ }^{4} Z$. Sekawi \\ ${ }^{1}$ Institue of Bioscience, University Putra Malaysia, 43400 UPM Serdang, Selangor Darul Ehsan \\ ${ }^{2}$ Department of Food Science, Faculty of Food Science and Technology, \\ University Putra Malaysia, 43400 UPM Serdang, Selangor Darul Ehsan \\ ${ }^{3}$ Department of Microbiology, Faculty of Biotechnology and Biomolecular Sciences, \\ University Putra Malaysia, 43400 UPM Serdang, Selangor Darul Ehsan \\ ${ }^{4}$ Department of Medical Microbiology and Parasitology, Faculty of Medicine and Health Sciences, \\ University Putra Malaysia, 43400 UPM Serdang, Selangor Darul Ehsan, Malaysia
}

\begin{abstract}
Problem statement: Plant antioxidants are natural plant products that inhibit the adverse effects of the Reactive Oxygen Species (ROS) produced in plants. Thus, antioxidants enable plants to survive. Depending on this principle, human beings started using some plants' parts to cure from diseases many centuries ago, even before the discovery of microbes or disclosing the etiology of many human diseases. Shed light on the importance of diet and natural products that have proved of great health impact on human traditionally and scientifically, disclosing the central role of natural antioxidants in this matter. Moreover, this review tried to give an overview on the research has so far done in Asian countries particularly in the field of natural antioxidants during the period 2000-2008. Therefore, the aim of this review is to present a comprehensive index for the antioxidant property of herbs and plants that have been traditionally used as well as experimentally proved beneficial in these countries. Approach: We had compared Asian and other nation's diet in the popularity of the traditional medicine and the type of daily meal in respect to their antioxidants contents and valuable health promoting effects. Many literatures had been collected using online search engines and the main library of University Putra Malaysia. The gathered data had been arranged alphabetically in a table depending on the plant's scientific name, common name, the used part(s) and the family name. Results: The research had shown that there were seventy-six plants with proved antioxidant activity which had been well studied by Asian scientists in the chosen period of time. Conclusion: The antioxidant components of the natural products constitute the major source of human health promotion and maintenance. The nature is still the perfect source for health promotion and for the supplementation of safe drugs. Great attention is mandatory from all the scientists around the world to explore many underestimated plants with highly effective antioxidant activity.
\end{abstract}

Key words: Dietary supplements, herbs, medicinal food, natural products, spice

\section{INTRODUCTION}

Since antiquity, man has used plants to treat common infectious diseases and some of these traditional medicines are still included as part of the habitual treatment of various maladies ${ }^{[1]}$. Virtually all cultures around the globe have relied historically and continue to rely on medicinal plants for primary health care. There is currently a worldwide upsurge in the use of herbal preparations and the active ingredients isolated from medicinal plants in health care ${ }^{[2]}$.
Long before, mankind discovered the existence of microbes, the idea that certain plants had healing potential, indeed, that they contained what we would currently characterize as antimicrobial principles ${ }^{[1]}$. Plant-based drugs have been used worldwide in traditional medicines for the treatment of various diseases. Approximately $60 \%$ of world's population still relies on medicinal plants for their primary healthcare. According to a survey by NCI, USA, $61 \%$ of the 877 small-molecule new chemical entities introduced as drugs worldwide during 1981-2002 were inspired by

Corresponding Author: F. Abu Bakar, Department of Food Science, Faculty of Food Science and Technology, University Putra Malaysia, 43400 UPM Serdang, Selangor Darul Ehsan, Malaysia Tel.: 00-60-3 89468375 Fax: 00-60-3 89423552 
natural products ${ }^{[3]}$. In USA, herbal preparations are becoming more popular and used increasingly ${ }^{[4]}$. There is a long history of medicinal use of plants in Asian countries, some of which have proved useful to humans as pharmaceuticals. Therefore Asia seems to be the most promising region for discovering novel biologically-active substances from its flora ${ }^{[5-7]}$.

There is currently a large and ever-expanding global population base that prefers the use of natural products in treating and preventing medical problems. This has influenced many of pharmaceutical companies to produce new antimicrobial formulations extracted from plants or herbs. Herbs are from natural plants and therefore often considered to be harmless compared with western medicines ${ }^{[4]}$. Plant species still serve as a rich source of many novel biologically active compounds. However, very few plant species have been thoroughly investigated for their medicinal properties. Thus, there is renewing interest in phytomedicine during last decade and nowadays many medicinal plant species are being screened for pharmacological activities $^{[3]}$. At present, plant and herb resources are unlimited. Natural products from plants have provided the pharmaceutical industry with one of its most important sources of lead compounds and up to $40 \%$ of modern drugs are derived from natural sources, using either the natural substance or a synthesized version ${ }^{[2]}$.

Epidemiological studies have shown an inverse relationship between vegetarian dietary practices and the incidence of cancer, cardiovascular diseases and mortality ${ }^{[8]}$. Similar outcomes were also observed in countries where animal-based foods are included in the diet but the intake of plant-based foods was high ${ }^{[9]}$. This suggests a potential therapeutic role of edible plants in human health. Traditional Asian diet contains less animal fats and higher plant-based foods as it is compared to western diet. Such a higher consumption of plant foods in Asian countries as a result of their tropical climates, results in a wider choice of edible plants $^{[10]}$. Epidemiological studies suggested that the habit of vegeteranian food is associated with reduced risk of cancer, cardiovascular and neurodegenerative disorders ${ }^{[11]}$. Consistent with this hypothesis, the incidence of these disorders is least in Asian populations where fruits, vegetables and spices are the major elements in the human diet ${ }^{[11]}$. Diet can modify the pathophysiological processes of various metabolic disorders and can be an effective preventive strategy for various disease processes most of which are known to involve oxidative damage ${ }^{[12]}$.

The aim of this review is to give a comprehensive outlook on the progress of the medicinal plants' research in the continental Asia on antioxidants, antiradiation, anti-lipid peroxidation and free radicals scavenging plants as well as focusing on the most important and recent findings. This review has been grouped into two parts; essays and a table. The essays encompasses introduction, methodology, impact of alternative medicine in Asia and the world, the importance of plants as a source for antioxidant substances, the plants' components rich in antioxidants, the antioxidants as free radicals scavengers, the antilipid peroxidation and immune modulatory effects of antioxidants, two examples on the most researched antioxidant's plants in Asia and finally the role of natural products as radioprotectors. In addition, many examples have been mentioned within the text discussing the biological potential and antioxidant activities of some of the most prominent plants and herbs that were investigated in elegant Asian research. Furthermore, the complete list of research conducted in Asia on antioxidants plants, herbs and natural products' components has been shown in Table 1 which summarizes those studies based on the plant's scientific and common name, the family name as well as the used $\operatorname{part}(\mathrm{s})$.

Table 1: Potent antioxidant medicinal plants explored by Asian scientists in the period from 2000-2008. Plants are ordered alphabetically on the families' names

\begin{tabular}{|c|c|c|c|c|c|}
\hline Scientific name & Common name & Family & Used part(s) & Medical usage & Reference no. \\
\hline Amaranthus gangeticus L. & $\begin{array}{l}\text { Red spinach or elephant head } \\
\text { amaranth }\end{array}$ & Amaranthaceae & Leaf & Antioxidant & {$[99-101]$} \\
\hline Amaranthus spinosus L. & Spiny amaranth & Amaranthaceae & Leaf & Antioxidant & {$[99,102,103]$} \\
\hline Anacardium occidentale L. & Cashew & Anacardiaceae & Shoot & Antioxidant & {$[99,100,104]$} \\
\hline Apium graveolens $\mathrm{L}$. & Local celery & Apiaceae & Leaf & Antioxidant & {$[99,100]$} \\
\hline Daucus carota $\mathrm{L}$. & Carrot & Apiaceae & Root & Antioxidant & {$[99,100,105,106]$} \\
\hline $\begin{array}{l}\text { Colocasia esculentum } \\
\text { var. antiquorum (Schott) } \\
\text { F.T. Hubb. and Rehder }\end{array}$ & Elephant ear & Araceae & $\begin{array}{l}\text { Leaf } \\
\text { talk }\end{array}$ & Antioxidant & {$[99,100]$} \\
\hline Calamus scipionum Lour. & No common name & Arecaceae & Leaf & Antioxidant & {$[99,100,104]$} \\
\hline Elaeis guineensis (L.) Jacq. & African oil palm & Arecaceae & Frond & $\begin{array}{l}\text { Antioxidant, } \\
\text { vasorelaxation properties } \\
\text { and } \mathrm{LDLr}^{*} \text { modulation } \\
\text { effects }\end{array}$ & {$[104,107]$} \\
\hline
\end{tabular}


Am. J. Pharm. \& Toxicol., 4 (3):56-74, 2009

\begin{tabular}{|c|c|c|c|c|c|}
\hline $\begin{array}{l}\text { Bidens pilosa Linn. } \\
\text { Var. radiata }\end{array}$ & Hairy Beggarticks & Asteraceae & $\begin{array}{l}\text { Whole } \\
\text { plant }\end{array}$ & $\begin{array}{l}\text { Antioxidant and } \\
\text { NO** inhibitory }\end{array}$ & [27] \\
\hline $\begin{array}{l}\text { Diplazium esculentum } \\
\text { (Retzius) }\end{array}$ & Swartz & Vegetable fern & Athyriaceae & Shoot Antioxidant & {$[99,100,108,109]$} \\
\hline Brassica alboglabra Bailey & Chinese kale & Brassicaceae & leaves & Antioxidant & {$[99,100,110]$} \\
\hline Brassica oleracea $\mathrm{L}$. & $\begin{array}{l}\text { Cauliflower, Broccoli, Cabbage } \\
\text { and Chinese cabbage }\end{array}$ & Brassicaceae & Flower leaves & Antioxidant & {$[100]$} \\
\hline Raphanus sativus L. & White radish & Brassicaceae & Root & Antioxidant & {$[99,100,111]$} \\
\hline $\begin{array}{l}\text { Gynandropsis gynandra } \\
\text { (L.) }\end{array}$ & Briq. & Cat's whisker & $\begin{array}{l}\text { Capparaceae } \\
\text { Leaf }\end{array}$ & $\begin{array}{l}\text { Antioxidant, LDLr } \\
\text { modulation effects and } \\
\text { Vascular relaxation } \\
\text { properties }\end{array}$ & {$[99,100,104,112]$} \\
\hline Carica papaya $\mathrm{L}$. & Papaya & Caricaceae & Shoots & $\begin{array}{l}\text { Antioxidant, LDLr } \\
\text { modulation effects and } \\
\text { vasorelaxation properties }\end{array}$ & {$[99,100,104,107,112]$} \\
\hline \multirow[t]{6}{*}{$\begin{array}{l}\text { Garcinia atroviridis } \\
\text { Griff. ex T. Anders }\end{array}$} & Asam gelugur & Clusiaceae & Fruits & $\begin{array}{l}\text { Antioxidant, antitumour } \\
\text { and antibacterial, } \\
\text { Bacillus subtilis (mutant), } \\
\text { B. subtilis (wild-type), } \\
\text { methicillin-resistant } \\
\text { S. aureus, Escherichia coli, } \\
\text { Pseudomonas aeruginosa } \\
\text { and antifungal }\end{array}$ & {$[99,100,113]$} \\
\hline & & & & Cladosporium herbarum & {$[99,100,113]$} \\
\hline & & & Leaves & $\begin{array}{l}\text { Antioxidant, antitumour } \\
\text { and antibacterial, B. subtilis } \\
\text { (mutant), B. subtilis } \\
\text { (wild-type), methicillin- } \\
\text { resistant } S \text {. aureus, } \\
\text { P. aeruginosa and antifungal } \\
\text { C. herbarum }\end{array}$ & \\
\hline & & & Stem bark & $\begin{array}{l}\text { Antioxidant, antitumour and } \\
\text { antibacterial, B. subtilis } \\
\text { (mutant), B. subtilis (wild- } \\
\text { type), methicillin-resistant } \\
\text { S. aureus, E. coli and } \\
\text { P. aeruginosa }\end{array}$ & {$[99,100,113]$} \\
\hline & & & Trunk bark & $\begin{array}{l}\text { Antioxidant, antitumour and } \\
\text { antibacterial, B. subtilis } \\
\text { (mutant), B. subtilis (wild- } \\
\text { type), methicillin-resistant } \\
\text { S. aureus and } P \text {. aeruginosa }\end{array}$ & {$[99,100,113]$} \\
\hline & & & Roots & $\begin{array}{l}\text { Antioxidant, antitumour and } \\
\text { antibacterial, B. subtilis } \\
\text { (mutant), B. subtilis (wild- } \\
\text { type),methicillin-resistant } \\
\text { S. aureus, E. coli and } \\
\text { P. aeruginosa }\end{array}$ & {$[113,114]$} \\
\hline Ipomoea aquatic & Water spinach & Convolvulaceae & Leaf & Antioxidant & {$[99,100]$} \\
\hline Ipomoea batatas $\mathrm{L}$. & Sweet potato & Convolvulaceae & Shoots & $\begin{array}{l}\text { Antioxidant and LDLr } \\
\text { modulation effects }\end{array}$ & {$[99,104,115-119]$} \\
\hline $\begin{array}{l}\text { Cucurbita maxima Duch. } \\
\text { ex. Lam. }\end{array}$ & Pumpkin & Cucurbitaceae & Fruit & Antioxidant & {$[99,100,115]$} \\
\hline Luffa acutangula Roxb. & Angular loofah & Cucurbitaceae & Fruit & Antioxidant & {$[99,100,120]$} \\
\hline Momordica charantia L. & Bitter melon & Cucurbitaceae & Fruit & Antioxidant & {$[121-124]$} \\
\hline Trichosanthes anguina $\mathrm{L}$. & Snake gourd & Cucurbitaceae & Fruit & Antioxidant & {$[99,100]$} \\
\hline $\begin{array}{l}\text { Elaeocarpus kontumensis } \\
\text { Gagnep. }\end{array}$ & No common name & Elaeocarpaceae & Bark & Antimalarial & {$[125]$} \\
\hline Manihot utilissima Pohl. & Cassava & Euphorbiaceae & Shoots & Antioxidant and antitumour & {$[99,100,108]$} \\
\hline Sauropus androgynus (L.) & Star gooseberry & Euphorbiaceae & Leaf & Antioxidant & {$[99,100]$} \\
\hline Merr. & & & Shoot & Antioxidant and antitumour & {$[108]$} \\
\hline $\begin{array}{l}\text { Glycine max (Linnaeus) } \\
\text { Merrill }\end{array}$ & Soybean & Fabaceae & Sprout & Antioxidant & {$[99,100,126,127]$} \\
\hline Pachyrrhizus erosus Linn. & Sinkamas & Fabaceae & Root & Antioxidant & {$[99,100]$} \\
\hline Parkia speciosa Hassk & Stink bean & Fabaceae & Seed/bean & Antioxidant & [99] \\
\hline
\end{tabular}


Am. J. Pharm. \& Toxicol., 4 (3):56-74, 2009

Table 1: Continued

\begin{tabular}{|c|c|c|c|c|c|}
\hline Phaseolus aureus Roxb. & Mung bean & Fabaceae & Sprout & Antioxidant & {$[99,100,128]$} \\
\hline Phaseolus vulgaris Linnaeus & Dwarf bean & Fabaceae & Seed/bean & Antioxidant & {$[28,99,100,129,130]$} \\
\hline Pisum sativum $\mathrm{L}$. & Shelling peas & Fabaceae & Seed/bean & Antioxidant & {$[99,100,131]$} \\
\hline $\begin{array}{l}\text { Psophocarpus tetragonolobus } \\
\text { DC. }\end{array}$ & Winged bean & Fabaceae & Seed/bean & Antioxidant & [99] \\
\hline $\begin{array}{l}\text { Sesbania grandifolia } \\
\text { (L.) Pers. }\end{array}$ & Butterfly Tree or agati & Fabaceae & Leaf & Antioxidant & {$[99,100]$} \\
\hline Vigna sinensis (L.) Savi & String bean or green bean & Fabaceae & Seed/bean & Antioxidant & {$[99,132]$} \\
\hline Centella asiatica (L.) Urb. & Pegaga or gotu kola & Hydrocotylaceae & Leaf & Antioxidant & {$[58,99,100,133,134]$} \\
\hline Mentha agrestis Soll. & Japanese mint & Lamiaceae & Leaf & $\begin{array}{l}\text { Antioxidant and LDLr } \\
\text { modulation effects }\end{array}$ & {$[99,100,104,112]$} \\
\hline Leea indica (Burm.f.) Merr. & Bandicoot berry & Leeaceae & Whole plant & $\begin{array}{l}\text { Antioxidant and } \\
\text { NO inhibitory }\end{array}$ & [135] \\
\hline Allium odorum L. & Chinese chives & Liliaceae & Leaves & Antioxidant & {$[99,100]$} \\
\hline Allium fistulosum $\mathrm{L}$. & Welsh Onion & Liliaceae & Leaves & Antioxidant & {$[99,100]$} \\
\hline Allium sativum $\mathrm{L}$. & Common garlic & Liliaceae & Root & Antioxidant & {$[99,100,136,137]$} \\
\hline $\begin{array}{l}\text { Hibiscus esculentus } \\
\text { (L.) Moench }\end{array}$ & Lady's fingers & Malvaceae & Fruit & Antioxidant & {$[138]$} \\
\hline Hibiscus sabdarifa L. & Roselle & Malvaceae & Calyx & $\begin{array}{l}\text { LDL antioxidant and LDLr } \\
\text { modulation effects }\end{array}$ & [104] \\
\hline Musa sapientum L. & Common banana & Musaceae & Flower & Antioxidant & [139-141] \\
\hline Psidium guajava L. & Guava & Myrtaceae & Fruit & Antioxidant & {$[142,143]$} \\
\hline Capsicum frutescens $\mathrm{L}$. & Bird chili & Solanaceae & Fruit & $\begin{array}{l}\text { Antioxidant, LDLr } \\
\text { modulation effects and } \\
\text { vasorelaxation properties }\end{array}$ & {$[99,100,104,107,112]$} \\
\hline Lycium chinense Mill. & Chinese Wolf-berry & Solanaceae & Leaf & Antioxidant & {$[99,100,144,145]$} \\
\hline Solanum melongena $\mathrm{L}$. & Egg plant & Solanaceae & Fruit & Antioxidant & {$[100,146-149]$} \\
\hline Lycium chinense Mill. & Chinese Wolf-berry & Solanaceae & Leaf & Antioxidant & {$[99,100]$} \\
\hline Solanum melongena $\mathrm{L}$. & Egg plant & Solanaceae & Fruit & Antioxidant & {$[100]$} \\
\hline Chasalia chartacea & No common name & Rubiaceae & Whole plant & Antioxidant and NO inhibitory & {$[135]$} \\
\hline Hedyotis verticillata $\mathrm{L}$. & Hedyotis plant & Rubiaceae & Whole plant & Antioxidant and NO inhibitory & {$[135]$} \\
\hline $\begin{array}{l}\text { Lasianthus oblongus } \\
\text { King and Gamble }\end{array}$ & No common name & Rubiaceae & Whole plant & $\begin{array}{l}\text { Antioxidant and NO } \\
\text { inhibitory }\end{array}$ & [135] \\
\hline Morinda citrifolia $\mathrm{L}$. & Indian mulberry & Rubiaceae & $\begin{array}{l}\text { Leaf } \\
\text { (whole leaf) }\end{array}$ & $\begin{array}{l}\text { Antioxidant, LDLr } \\
\text { modulation effects and } \\
\text { Vascular relaxation properties }\end{array}$ & {$[52,53,104,112]$} \\
\hline Morinda elliptica Ridley & Magic fruit & Rubiaceae & Leaf & Antioxidant & {$[51,150]$} \\
\hline Psychotria rostrata Blume & No common name & Rubiaceae & Leaf and Stem & Antioxidant & {$[135,151,152]$} \\
\hline Spermacoce articularis L. f. & poaia & Rubiaceae & Whole plant & Antioxidant and NO inhibitory & {$[135]$} \\
\hline $\begin{array}{l}\text { Spermacoce exilis (L. O. } \\
\text { Williams) C. D. Adams }\end{array}$ & Pacific false buttonweed & Rubiaceae & Whole plant & Antioxidant & {$[135]$} \\
\hline Citrus hystrix D.C & Kaffir lime & Rutaceae & Leaf & Antioxidant & {$[99,100]$} \\
\hline Thea chinensis Sims. & Green tea & Theaceae & Leaf & Antioxidant & {$[99,100]$} \\
\hline Piper sarmentosum Roxb. & Sireh & Piperaceae & Leaf & Antioxidant & {$[51,99,100,153]$} \\
\hline Polygonum minus Huds. & Small smartweed/ kesum & Polygonaceae & Leaf & Antioxidant & {$[99,100]$} \\
\hline Alpinia hookeriana Val. & No common name & Zingiberaceae & $\begin{array}{l}\text { Rhizome and } \\
\text { root parts }\end{array}$ & $\begin{array}{l}\text { Antioxidant and antibacterial } \\
\text { (P. aeruginosa, B. subtilis) } \\
\text { and antifungal } \\
\text { (Aspergillus ochraceous) }\end{array}$ & {$[154]$} \\
\hline Alpinia mutica Roxb. & $\begin{array}{l}\text { Small Shell Ginger or } \\
\text { Orchid Ginger }\end{array}$ & Zingiberaceae & $\begin{array}{l}\text { Rhizome and } \\
\text { root parts }\end{array}$ & $\begin{array}{l}\text { Antioxidant and antibacterial } \\
\text { (P. aeruginosa, B. subtilis) } \\
\text { and antifungal }(\text { A. ochraceous })\end{array}$ & [154] \\
\hline Alpinia nutans Rosc. & Ginger Lily or Shell Ginger & Zingiberaceae & $\begin{array}{l}\text { Rhizome and } \\
\text { root parts }\end{array}$ & $\begin{array}{l}\text { Antioxidant and antibacterial } \\
(P \text {. aeruginosa, } B \text {. subtilis }) \\
\text { and antifungal }(\text { A. ochraceous })\end{array}$ & [154] \\
\hline $\begin{array}{l}\text { Alpinia rafflesiana } \\
\text { Wall. ex. Bak. }\end{array}$ & Raffles' Alpinia & Zingiberaceae & $\begin{array}{l}\text { Rhizome and } \\
\text { root parts }\end{array}$ & $\begin{array}{l}\text { Antioxidant and antibacterial } \\
\text { ( } P \text {. aeruginosa, B. subtilis) } \\
\text { and antifungal ( } \text { A. ochraceous) }\end{array}$ & [154,155] \\
\hline $\begin{array}{l}\text { Alpinia vitellina (Lindl.) } \\
\text { Ridl. }\end{array}$ & No common name & Zingiberaceae & $\begin{array}{l}\text { Rhizome and } \\
\text { root parts }\end{array}$ & $\begin{array}{l}\text { Antioxidant and antibacterial } \\
\text { (P. aeruginosa, B. subtilis) } \\
\text { and antifungal }(\text { A. ochraceous })\end{array}$ & [154] \\
\hline Costus discolor Rosc. & Setawar putih & Zingiberaceae & $\begin{array}{l}\text { Rhizome and } \\
\text { root parts }\end{array}$ & $\begin{array}{l}\text { Antioxidant and antibacterial } \\
\text { ( } P \text {. aeruginosa, B. subtilis }) \\
\text { and antifungal }(\text { A. ochraceous })\end{array}$ & [154] \\
\hline $\begin{array}{l}\text { Costus megalobractea } \mathrm{K} \text {. } \\
\text { Schum. }\end{array}$ & No common name & Zingiberaceae & $\begin{array}{l}\text { Rhizome and } \\
\text { root parts }\end{array}$ & $\begin{array}{l}\text { Antioxidant and antibacterial } \\
\text { (P. aeruginosa, B. subtilis) } \\
\text { and antifungal }(\text { A. ochraceous })\end{array}$ & [154] \\
\hline
\end{tabular}


Am. J. Pharm. \& Toxicol., 4 (3):56-74, 2009

\begin{tabular}{|c|c|c|c|c|c|}
\hline Costus spiralis Rosc. & Spiral ginger & Zingiberaceae & $\begin{array}{l}\text { Rhizome and } \\
\text { root parts }\end{array}$ & $\begin{array}{l}\text { Antioxidant and antibacterial } \\
\text { (P. aeruginosa, B. subtilis) } \\
\text { and antifungal (A. ochraceous) }\end{array}$ & ) \\
\hline Costus villosissimus Jacq. & Spiral flag & Zingiberaceae & $\begin{array}{l}\text { Rhizome and } \\
\text { root parts }\end{array}$ & $\begin{array}{l}\text { Antioxidant and antibacterial } \\
\text { (P. aeruginosa, B. subtilis) } \\
\text { and antifungal (A. ochraceous) }\end{array}$ & \\
\hline Curcuma longa $\mathrm{L}$. & Turmeric & Zingiberaceae & Root & Antioxidant and antitumour & {$[99,100,156]$} \\
\hline $\begin{array}{l}\text { Curcuma mangga Valeton } \\
\text { and van Zijp }\end{array}$ & Mango ginger & Zingiberaceae & Rhizome & $\begin{array}{l}\text { Antioxidant, antitumour and } \\
\text { antiallergic }\end{array}$ & {$[157,158]$} \\
\hline $\begin{array}{l}\text { Etlingera elatior (Jack) } \\
\text { R. M. Sm. }\end{array}$ & Torch ginger & Zingiberaceae & Flower & Antioxidant & {$[99,100]$} \\
\hline Zingiber cassumunar Roxb. & Cassumunar ginger or Thai ginger & Zingiberaceae & $\begin{array}{l}\text { Rhizome and } \\
\text { root parts }\end{array}$ & $\begin{array}{l}\text { Antioxidant and antibacterial } \\
\text { (P. aeruginosa, B. subtilis) } \\
\text { and antifungal }(\text { A. ochraceous })\end{array}$ & [154] \\
\hline & & & Rhizome & Antiallergic & {$[158]$} \\
\hline Zingiber ottensii Val. & Black cleanser & Zingiberaceae & $\begin{array}{l}\text { Rhizome and } \\
\text { root parts }\end{array}$ & $\begin{array}{l}\text { Antioxidant and antibacterial } \\
\text { (P. aeruginosa, B. subtilis) } \\
\text { and antifungal (A. ochraceous) }\end{array}$ & [154] \\
\hline Zingiber macroglossum Val. & No common name & Zingiberaceae & $\begin{array}{l}\text { Rhizome and } \\
\text { root parts }\end{array}$ & $\begin{array}{l}\text { Antioxidant and antibacterial } \\
\text { (P. aeruginosa, B. subtilis) } \\
\text { and antifungal }(\text { A. ochraceous) }\end{array}$ & \\
\hline
\end{tabular}

*: LDLr: Low Density Lipid receptor; **: NO: Nitric Oxide

\section{MATERIALS AND METHODS}

The data of this review was collected using Pubmed, Scopus databases and Google scholar search engine. Endnote program was used to edit reference formatting. Moreover, it's worth mentioning that the central library of University Putra Malaysia was as a data source for retrieving books and needed resources.

The alternative medicine in Asia and other parts of the world: India is one of the twelve mega diversity countries in the world. It has a vital stake in the conservation and sustainable utilization of its biodiversity resources ${ }^{[13]}$. India has been recognized for its spices and medicinal plants which exhibit a wide range of physiological and pharmacological properties. Herbs and spices have a traditional history of use, with a remarkable role in the cultural heritage of appreciating food and its links to health. Current biomedical efforts are focused on their scientific merits, to provide science-based evidence for the traditional uses and to develop either functional foods or nutraceuticals ${ }^{[14]}$. Plant foods contain phytochemicals such as flavonoids, phenolic acids, used to show a remarkable biological activity. Some common foods used in Indian culinary practices were assessed for their anti-oxidant, anti-mutagenic, anti-carcinogenic effects, vitamin $D$ activity and were evaluated for their plausible biological effects ${ }^{[12]}$. Away from India, the traditional Korean medicine, So-Cheong-Ryong-Tang (SCRT) also called as Xiao-qing-long-tang or Shoseiru-to, contains eight species of medicinal plants which have been used for treating allergic diseases, such as allergic rhinitis and asthma for hundreds of years in Asian countries ${ }^{[7]}$. A recent study in Korea revealed that SCRT can correct Th2 dominant condition by affecting directly on the $\mathrm{CD} 4+\mathrm{T}$ cell without significantly depressing general $\mathrm{T}$ cell activities ${ }^{[15]}$. Malaysia has been found to possess huge biodiversity resources and potential for natural products and is also considered as mega diversity country. These countries together contain at least $60 \%$ of the world's known species ${ }^{[16]}$. The flora of Malaysia is exceedingly rich and is conservatively estimated to contain about 12,500 species of flowering plants and more than 1,100 species of ferns and fern allies. Many of these species are unique and found nowhere else in the world. Out of the 12,000 species of vascular plants, $10 \%$, or approximately 1200 species, are reported to have medicinal properties ${ }^{[17]}$. In Peninsular Malaysia, for example, well over $26 \%$ of the tree species are endemic. Higher endemism is expected in the herbaceous flora with some of the larger genera estimated to be endemic in more than $80 \%$ of their species. Many endemic plants are localized in their distribution, being found only in a few valleys or mountain tops ${ }^{[18,19]}$. Malaysia alone has about 1300 medicinal plant products registered by the Ministry of Health and are available in market ${ }^{[20]}$. Although these medicinal plants or herbs have been used as a cure or for health since the olden days, they are now widely used especially in the pharmaceutical, health and food industries. These herbs are also used in cooking, cosmetics, perfumes and as flavors ${ }^{[18]}$. In comparison to Asian countries, there are about 1500 species of medicinal and aromatic plants in all 
Europe which have been widely used in countries such as Albania, Bulgaria, Croatia, France, Germany, Hungary, Poland, Spain, Turkey and United Kingdom $^{[21]}$. Another study found that a total of only 985 species have been catalogued in the Mediterranean countries, of which only 406 have medicinal use ${ }^{[22]}$. By this simple comparison we can estimate the huge number of plant species founds in Asia which is astoundingly inspiring for researchers to explore their medicinal benefit.

Countries in Africa, Asia and Latin America use Traditional Medicine (TM) to help meet some of their primary health care needs. In Africa, up to $80 \%$ of the population uses traditional medicine for primary health care while in industrialized countries, adaptations of traditional medicine are termed "Complementary "or "Alternative" Medicine (CAM) ${ }^{[23]}$. The WHO fact sheet 2003 gave a short description on different countries around the world regarding the practicing of the alternative medicine by their people:

- In China, traditional herbal preparations account for $30-50 \%$ of the total medicinal consumption

- In Ghana, Mali, Nigeria and Zambia, the first line of treatment for $60 \%$ of children with high fever resulting from malaria is the use of herbal medicines at home

- WHO estimates that in several African countries traditional birth attendants assist in the majority of births

- In Europe, North America and other industrialized regions, over $50 \%$ of the population have used complementary or alternative medicine at least once

- In San Francisco, London and South Africa, 75\% of people living with HIV/AIDS use TM/CAM

- $70 \%$ of the population in Canada have used complementary medicine at least once

- In Germany, $90 \%$ of the population has used a natural remedy at some point in their life. Between 1995 and 2000, the number of doctors who had undergone special training in natural remedy medicine had almost doubled to 10,800

- In the United States, 158 million of the adult population use complementary medicines and according to the USA Commission for Alternative and Complementary medicines, US $\$ 17$ billion was spent on traditional remedies in 2000

- In the United Kingdom, annual expenditure on alternative medicine is US \$230 million

- The global market for herbal medicines currently stands at over US $\$ 60$ billion annually and is growing steadily ${ }^{[24]}$
Plants' antioxidants:

Why plants are huge source of antioxidants: Plants are potential sources of natural antioxidants. They absorb the sun's radiation and generate high levels of oxygen as secondary metabolites of photosynthesis. On the other hand, Oxygen is easily activated by Ultra Violet (UV) radiation and heat from the sunlight to produce toxic Reactive Oxygen Species (ROS) ${ }^{[25]}$. These ROS are highly reactive because they can interact with a number of cellular molecules and metabolites thereby leading to a number of destructive processes causing cellular damage ${ }^{[26]}$. Plants produce various antioxidative, enzymes and non-enzymes, compounds to counteract and detoxify these ROS in order to survive. Hence, naturally occurring phytocompounds possessing antioxidative and antiinflammatory properties appear to contribute to their chemopreventive or chemoprotective activity ${ }^{[27]}$ which in turn, by the alternative medicine, has been used to the benefit of human beings.

Plants' most abundant antioxidant substances: Phenolic substances, which are known to possess high antioxidative activity, are actually common phytochemicals in fruits and leafy vegetables. Plants containing phenolic compounds have been reported to possess strong antioxidant properties ${ }^{[28]}$. Most of these phenolics are classified into two principal groups of phenol; carboxylic acids and flavonoids, the latter being the most significant ${ }^{[29,30]}$. According to $\operatorname{Pratt}^{[31]}$, phenolic compounds are found abundantly in all parts of the plant, such as wood, bark, stems, leaves, fruit, root, flowers, pollen and seeds. Antioxidative activity of phenolic compounds is based on their ability to donate hydrogen atoms to free radicals ${ }^{[32]}$. Many phenolic compounds, particularly flavonoids, exhibit a wide range of biological effects, including antioxidant activity, antibacterial, antiviral, anti-inflammatory, antiallergic, anti-thrombotic, vasdilatory actions and the ability to lower the risk of coronary heart diseases ${ }^{[33]}$. The protective effects of diets high in fruits and vegetables have been attributed to the presence of these compounds ${ }^{[34]}$. A study on the plant extracts of Bidens pilosa L. var. radiata (Asteraceae) revealed that it could serve as a good source of caffeoylquinic acid derivatives and flavonoid glycosides which are attributed to Bidens pilosa significant antioxidant activity and inhibitory effect on Nitric Oxide (NO) production (an inflammatory mediator) in macrophages. Therefore, the study proposed the potential dietary value and benefits of Bidens pilosa extract on the basis of the phytochemical characteristics and the observed bioactive properties ${ }^{[27]}$. Another 
example of the antioxidant effect of flavoniods, is Scutellaria baicalensis Georgi (Lamiaceae); a widely used herb in traditional medical systems of China and Japan. The major constituents of $S$. baicalensis are flavonoids: baicalein, baicalin, wogonin, which have been associated with various properties, for example: Antioxidant, anti-inflammatory, antithrombotic, antibacterial and antiviral $^{[35]}$.

The antioxidants and free radicals scavenging bioactivity: The term, antioxidant is used to describe a dietary component that can function to decrease tissue damage by reactive oxygen ${ }^{[36]}$. A good example of potent plants' antioxidants are anthocyanins, which are water-soluble pigments present in plants ${ }^{[37]}$. They are known to be powerful antioxidants that help protect plants from UV damage, particularly, UVB radiation which proves to be one of the most relevant environmental risks because of its hazardous effects to human being, such as premature skin aging and especially skin photocarcinogenesis ${ }^{[38,39]}$.

Most living organisms possess enzymatic and nonenzymatic defense systems against excessive production of reactive oxygen species; However, different external factors (smoke, diet, alcohol and some drugs) and aging decrease the efficiency of such protecting systems, resulting in disturbances of the redox equilibrium established under healthy conditions ${ }^{[40]}$. The homeostatic balance between Reactive Oxygen Species (ROS) and endogenous antioxidants is important in maintaining healthy tissues. Excessive ROS states are important in diseases such as acute respiratory distress syndrome and Idiopathic Pulmonary Fibrosis ${ }^{[41]}$. Redox imbalance increases the breakdown of the extracellular matrix component hyaluronan into lower molecular weight fragments that in turn activate innate immune responses and perpetuate tissue injury ${ }^{[42]}$. Thus, antioxidants that scavenge reactive oxygen species may be of great value in preventing the onset and propagation of oxidative diseases like autoimmune diseases, cardiovascular diseases, neurovascular diseases ${ }^{[43]}$. Recently, more attention has been paid to the role of natural antioxidants, mainly phenolic compounds, which may have higher antioxidant activities than those of conventional vitamins $\mathrm{C}, \mathrm{E}$ and $\beta$-carotene ${ }^{[44]}$. Therefore, antioxidants, which can neutralize free radicals, may be of central importance in the prevention of carcinogenicity, cardiovascular and neurodegenerative changes associated with aging ${ }^{[41,45]}$. Epidemiological studies showed that the consumption of vegetables and fruits could protect humans against oxidative damage by inhibiting or quenching free radicals and reactive oxygen species ${ }^{[46]}$.
Fruits and vegetables are rich sources of many food factors including vitamins, minerals and phytochemicals which may act as antioxidants ${ }^{[47]}$. The antioxidant activity of fruits and vegetables is often assumed to be of greatest importance in combating a number of degenerative diseases as free radical-related damage has been implicated in causing many of these conditions ${ }^{[48]}$. Thus a daily consumption of five or more servings of antioxidant-rich food provides the body with the essential antioxidants needed to prevent degenerative diseases, premature aging symptoms, chronic fatigue and general disability ${ }^{[49]}$. Doctors and nutritionist have long known that antioxidants are needed by the human body for optimal well being, especially for maintaining a healthy body system and defense mechanism against cell damage ${ }^{[50]}$. Therefore, the more the discovered antioxidant, the more the benefit to human beings has developed.

Vimala et al. ${ }^{[51]}$ found that the daily consumption of Piper sarmentosum Roxb. (kadok, Piperaceae) and Morinda elliptica Ridley (mengkudu jantanm, Rubiaceae) leaves, edible medicinal plants commonly used in Malaysian traditional medicine, can help maintain energy, general ability and fitness even during aging. Their findings were based on the truth that Naringenin, a naturally occurring antioxidant superoxide scavenger, was found in the methanolic leave extracts of $P$. sarmentosum and M. elliptica. Thus these plants could be considered as potent antioxidant food. Therefore if consumed daily, they could scavenge access free-radicals in the human biological system and could prevent oxidative related diseases ${ }^{[51]}$. Antioxidant food, supplies the body with the essential antioxidant nutrients needed to enhance the immune system, eliminate excess free radicals and keep the oxidative stress state in balance. In a similar study Zin et al. ${ }^{[52,53]}$, found that the consumption of Morinda citrifolia L. (Rubiaceae); locally known as (mengkudu), may have potential health effects. All the examined fractions, demonstrated high antioxidative activity; the potency of some of these compounds could provide a scientific basis for the health benefits claimed for M. citrifolia in folk medicine ${ }^{[52,53]}$.

Some of the Korean medicinal plants and their isolated polyphenols have exhibited effective radicalscavenging activity and may act as promising agents for scavenging free radicals and treating diseases associated with excess free radicals. For example the Rosaceae, Rosa rugosa Thunb. and Rosa davurica Pall. showed strong radical-scavenging activity. The most effective medicinal plant from families other than Rosaceae was Cedrela sinensis Juss. (Meliaceae), followed in order by Nelumbo nucifera Gaertn. 
(Nelumbonaceae), Eucommia ulmoides Oliver (Eucommiaceae), Zanthoxylum piperitum DC. (Rutaceae), Cudrania tricuspidata (Carrière) Bureau (Moraceae) and Houttuynia cordata Thunb. (Saururaceae) $^{[54]}$.

It is worth mentioning that synthetic antioxidants were found to be harmful to health while most of the natural antioxidants from plant source proved to be safer for health and possess better antioxidant activity ${ }^{[55]}$. This fact could explain our finding that most Asian scientists have focused their research on the antioxidant activity of the studied plants rather than the antimicrobial and antitumor or other biological activities. Nevertheless, the antioxidant activity of these plants could be considered as the basis for further possible investigations on their additional properties.

The anti-lipid peroxidation and immune modulatory effects of antioxidants: As an example for the indirect antioxidant effect of plants, the antioxidant potential in herbal barks extract of five therapeutically important medicinal plants native to India was investigated. They are Crataeva nurvala Buch.-Ham. (Capparidaceae), Buchanania lanzan Spreng. (Anacardium), A. marmelos (L.) Corr. (Rutaceae), Dalbergia sissoo Roxb. ex DC. (Fabaceae) and Cedrela toona Roxb. (Meliaceae). All of them showed an excellent lipid peroxidation inhibitory potential and a comparative high NO quenching capacity which was found to be the highest in C. nurvala. Hence, the bark of Crataeva nurvula has the highest antioxidant capacity ${ }^{[56]}$.

Spices and herbs which are abundant in the daily meals of Asian countries have been proved to possess high antioxidant activity that can be applied for preservation of lipids and reduce lipid peroxidation in biological systems ${ }^{[57]}$. The antioxidant activity of spice extracts are retained even after boiling for $30 \mathrm{~min}$ at 100 degrees $\mathrm{C}$, indicating that the spice constituents are resistant to thermal denaturation ${ }^{[58]}$. The antioxidant activity of these dietary spices suggests that in addition to imparting flavor to the food, they possess potential health benefits by inhibiting the lipid peroxidation ${ }^{[59]}$.

Some of the dietary constituents commonly used in Indian foods such as cloves (Syzygium aromaticum (L.) Merrill and Perry, Myrtaceae), licorice (Glycyrrhiza glabra L., Fabaceae), mace (aril of Myristica fragrans Houtt., Myristicaceae) and greater cardamom (Amomum subulatum Roxb., Zingiberaceae), were selected as the test samples to find their effect on the inhibition of lipid peroxidation in rat liver homogenate ${ }^{[60]}$. The results showed that spices used in this study have significant ability to inhibit lipid peroxidation due to their polyphenol content, strong reducing power and superoxide radical scavenging activity. Cloves showed the highest antioxidant activity probably due to the higher polyphenol content as compared to other spices ${ }^{[60]}$. A second example of bioactive effects of spices and herbs is a study by ${ }^{[58]}$ in which they used water and alcoholic extract $(1: 1)$ of commonly used spices (garlic, ginger, onion, mint, cloves, cinnamon and pepper). Their result revealed a dose-dependent oxidation inhibition of fatty acid and linoleic acid in the presence of soybean lipoxygenase. Among the spices tested, cloves exhibited the highest effect while onion showed the least antioxidant activity. The relative antioxidant activities decreased in the order of cloves, cinnamon, pepper, ginger, garlic, mint and onion. Spice mix namely ginger, onion and garlic; onion and ginger; ginger and garlic showed cumulative inhibition of lipid peroxidation thus exhibiting their synergistic antioxidant activity ${ }^{[58]}$.

Currently, research interest has focused on various herbs that possess hypolipidemic, antiplatelet, antitumor, or immune-stimulating properties that may be useful adjuncts in helping reduce the risk of cardiovascular disease and cancer ${ }^{[61]}$. In different herbs, a wide variety of active phytochemicals, including the flavonoids, terpenoids, lignans, sulfides, polyphenolics, carotenoids, coumarins, saponins, plant sterols, curcumins and phthalides have been identified ${ }^{[62]}$. In addition to delivering antioxidant and other properties, herbs and spices can be used in recipes to partially or wholly replace less desirable ingredients such as salt, sugar and added saturated fat. As several metabolic diseases and age-related degenerative disorders are closely associated with oxidative processes in the body, therefore the use of herbs and spices as a source of antioxidants to combat oxidation warrants further attention $^{[60,63]}$.

In the functioning processes of the immune system, such as phagocytosis, reactive oxygen and nitrogen species are generated ${ }^{[64]}$. The generation of Reactive Oxygen Species (ROS) by phagocytes is one of the irreplaceable microbicidal tools of innate immunity. If they are left unchecked they can affect the components of the immune system by inducing oxidative damage. This is more so in the elderly or during inflammation where there is excess generation of these reactive species than can be taken care of by the defenses in the form of antioxidants ${ }^{[65]}$. Dietary supplementation with antioxidants may greatly help in such conditions. There are some indications of possible benefits of antioxidant supplementation. Polyphenols have a well-known antioxidant-based immunomodulatory activities which can be as therapeutic agents in the inflammation-driven damaging oxidant load ${ }^{[66,67]}$. 
The two most researched plants with antioxidant activity in Asia: A prominent example of potent antioxidant spices is turmeric; Curcuma longa L. (Zingiberaceae). The Indian traditional medical systems have long used turmeric; a spice is often found in curry powder; for wound healing, rheumatic disorders, gastrointestinal symptoms, deworming, rhinitis and as a cosmetic and traditionally known for its an antiinflammatory effects ${ }^{[14,68]}$. Studies in India have explored its anti-inflammatory, cholekinetic and antioxidant potentials ${ }^{[69-71]}$. The recent investigations have focused on its preventive effects on precarcinogenic, anti-inflammatory and anti atherosclerotic effects both in vivo and in vivo conditions in animals and humans. Both turmeric and curcumin have been found to increase detoxifying enzymes, prevent DNA damage, improve DNA repair, decrease mutations and tumor formation and exhibit antioxidative potential in animals. Recent physiological, pharmacological and biochemical studies appear to support the wisdom of the traditional dietary practices ${ }^{[14]}$. Curcumin (diferuloylmethane), an orange-yellow and major component of turmeric; is responsible for its biological actions. Other extracts of this plant has been showing potency too ${ }^{[72,73]}$. In vivo, curcumin exhibits antiparasitic, antispasmodic, anti-inflammatory and gastrointestinal effects; and also inhibits carcinogenesis and cancer growth ${ }^{[73-76]}$. In vivo, there are experiments showing the anti-parasitic, anti-inflammatory potency of curcumin and extracts of C. longa L. by parenteral and oral application in animal models ${ }^{[74,77]}$. Curcumin has been shown in the last two decades to be a potent antioxidant and immunomodulatory agent that can modulate the activation of $\mathrm{T}$ cells, $\mathrm{B}$ cells, macrophages, neutrophils, natural killer cells and dendritic cells ${ }^{[77,78]}$. Curcumin can also downregulate the expression of various proinflammatory cytokines including TNF, IL-1, IL-2, IL-6, IL-8, IL-12 and chemokines, most likely through inactivation of the transcription factor NF-kappaB. Interestingly, however, curcumin at low doses can also enhance antibody responses. This suggests that curcumin's reported beneficial effects in arthritis, allergy, asthma, atherosclerosis, heart disease, Alzheimer's disease, diabetes and cancer might be due in part to its ability to modulate the immune system ${ }^{[68]}$.

The second example, Panax ginseng C.A. Meyer (Araliaceae) is a well-known medicinal herb native to China and Korea and has been used as a herbal remedy in Eastern Asia for thousands of years and is now a popular and worldwide used natural medicine. The active ingredients of ginseng are ginsenosides which are also called ginseng saponins ${ }^{[79]}$. However, there is different evidence of ginseng efficacy between Traditional Chinese Medicine (TCM), modern pharmacological experiments and clinical trials. In TCM, ginseng is a highly valued herb and has been applied to a variety of pathological conditions and illnesses such as hypodynamia, anorexia, shortness of breath, palpitation, insomnia, impotence, hemorrhage and diabetes ${ }^{[80]}$. Modern pharmacological experiments have proved that ginseng possesses multiple constituents (ginsenosides, polysaccharides, peptides, polyacetylenic alcohols), with actions (potent antioxidant activity, central nervous system effects, neuroprotective effect, immunomodulation, anticancer). And ginsenosides proved to be the part that posses the most of active ingredients, especially Ginsenosides Rg3, which proved to have antioxidant, antiinflammatory, antiapoptotic and immunostimulant properties $^{[81]}$. A recent study demonstrated the potential anti-rheumatoid activity of Panax ginseng C.A. Meyer head part and suggested that it has potential analgesic and anti-inflammatory activities ${ }^{[82]}$. Ginseng has also been studied on its effect mainly on physical, psychomotor performance and cognitive function ${ }^{[83,84]}$, immunomodulation, diabetes mellitus ${ }^{[85]}$, cardiovascular diseases ${ }^{[86]}$. Nevertheless, equivocal results have been demonstrated for many of these indications due to the poor quality of most clinical trials on ginseng ${ }^{[79]}$. Therefore, reliable clinical data in humans are still lacking and broader understanding of medical knowledge and reasoning on ginseng, is necessary ${ }^{[87]}$. A complete list of antioxidant plants researched in Asia is shown in Table 1.

The role of natural products as radioprotectors: Due to the increased use of ionizing radiation in various aspects of human life especially in areas pertaining to radiotherapy of cancer, food preservation, agriculture, industry and power generation, there is a need to develop an effective and non-toxic radioprotector ${ }^{[88]}$. No ideal and safe synthetic radioprotectors are available to date. So, the search for alternative sources, including plants, has been on going for several decades. In Ayurveda, the traditional Indian system of medicine, several plants have been used to treat free radicalmediated ailments and, therefore, it is logical to expect that such plants may also render some protection against radiation damage ${ }^{[89]}$. A systematic screening approach can provide leads to identifying potential new candidate drugs from plant sources, for mitigation of radiation injury ${ }^{[89]}$. The currently available radioprotectors have many drawbacks including high cost, side effects and toxicity ${ }^{[90]}$. Some antioxidant nutrients and phytochemicals have the advantage of low 
toxicity although they are generally protective when administered at pharmacological doses ${ }^{[91]}$. A number of phytochemicals, including caffeine, genistein and melatonin, have multiple physiological effects, as well as antioxidant activity, which resulted in radioprotection in $v i v{ }^{[91]}$. Several novel approaches are on the track to locate a potent radioprotector from plants. These include mimics of antioxidant enzymes $^{[92]}$, nitroxides, melatonin ${ }^{[93]}$, growth factors ${ }^{[94]}$, gene therapy ${ }^{[95]}$ and natural products ${ }^{[92,96]}$. The latter has several advantages since they are non-toxic with proven therapeutic benefits. Results from animal experiments indicated that antioxidant nutrients, such as vitamin $\mathrm{E}$ and selenium compounds, are protective against lethality and other radiation effects but to a lesser degree than most synthetic protectors ${ }^{[88]}$. As India and many Eastern countries have an enormous heritage of vast natural dietary and time tested medicinal resources; therefore, it is worth to explore the possibility of developing efficient, economically viable and clinically acceptable radioprotectors for human application from these resources ${ }^{[88]}$. For instance, Rosemarinus officinalis L. (Lamiacea) leave extract and Zingiber officinale Roscoe (Zingiberaceae) have been demonstrated to be good radioprotectors. The latter possesses antioxidant and neuromodulatory properties that can be effectively utilized for behavioral radioprotection $^{[97,98]}$.

\section{CONCLUSION}

As mentioned, the Reactive Oxygen Species (ROS) or oxidants, which are formed in the human body due to exogenous and endogenous factors, are found to be responsible for many diseases. Day by day, a lot of research have shown the potential of phytochemical antioxidants as health benefactors because of their ability to neutralize free radicals, reactive oxygen species, or oxidants responsible for the onset of cell damage. Taken together, it was concluded that first, antioxidant components of the natural products constitute the major source of human health promotion and maintenance. Moreover, antioxidant activity of the natural products includes detoxifying toxins, scavenging free radicals; wipe out the excess ROS and anti- lipids peroxidation. Indirectly, antioxidant components are useful as anticancer, anti-inflammatory, antimicrobial, antilipids, antiallergic and antidiabetics. The second main conclusion is that the nature is still the perfect source for health promotion and for the supplementation of safe drugs. Moreover, natural products and their antioxidant activity might represent the best solution to prevent the side effects of many commercially available drugs and to counteract the rapid emergence of multi-drug resistant microbes against the commonly used antimicrobial agents. Apart from the huge number of research studies in the filed of antioxidants discovery, this field still needs more attention from scientists around the world.

\section{ACKNOWLEDGMENT}

Appreciation goes to the Faculty of Food Science and Technology for supporting this review for the sake of establishing a comprehensive review on the antioxidant research in Asia.

\section{REFERENCES}

1. Rios, J.L. and M.C. Recio, 2005. Medicinal plants and antimicrobial activity. J. Ethnopharmacol., 100: 80-84.

http://www.ncbi.nlm.nih.gov/entrez/query.fcgi?cm $\mathrm{d}=$ Retrieve\& $\mathrm{db}=$ PubMed\&dopt $=$ Citation\&list_uids $=15964727$

2. Jassim, S.A.A. and M.A. Naji, 2003. Novel antiviral agents: A medicinal plant perspective. J. Applied Microbiol., 95: 412-427. http://www.ncbi.nlm.nih.gov/entrez/query.fcgi?cm $\mathrm{d}=$ Retrieve\& $\mathrm{db}=$ PubMed\&dopt $=$ Citation\&list_uids $=12911688$

3. Gautam, R., A. Saklani and S.M. Jachak, 2007. Indian medicinal plants as a source of antimycobacterial agents. J. Ethnopharmacol., 110: 200-234.

http://www.ncbi.nlm.nih.gov/entrez/query.fcgi?cm $\mathrm{d}=$ Retrieve\& $\mathrm{db}=$ PubMed\&dopt $=$ Citation\&list_uids $=17276637$

4. Hsieh, M.J., Z.S. Yen, S.C. Chen and C.C. Fang, 2008. Acute cholinergic syndrome following ingestion of contaminated herbal extract. Emerg. Med. J., 25: 781-782.

http://www.ncbi.nlm.nih.gov/entrez/query.fcgi?cm $\mathrm{d}=$ Retrieve $\& \mathrm{db}=$ PubMed\&dopt $=$ Citation\&list_uids $=18955628$

5. Hoareau, L. and E.J. Dasilva, 1999. Medicinal plants: A re-emerging health aid. Elect. J. Biotechnol., 2: 1-5.

http://www.ejb.org/content/vol2/issue2/full/2/

6. Perry, L.M. and J. Metzger, 1980. Medicinal Plants of East and Southeast Asia. MIT Press, Cambridge, ISBN: 0262160765, pp: 632.

7. Murakami, A., H. Ohigashi and K. Koshimizu, 1999. Chemoprevention, insights into biological mechanisms and promising food factors. Food Rev. Int., 15: 335-395. http://direct.bl.uk/bld/PlaceOrder.do?UIN=066688 $379 \&$ ETOC $=$ RN\& from $=$ searchengine 
8. Rajaram, S. and J. Sabaté, 2000. Health benefits of a vegetarian diet. Nutr. Rev., 16: 531-533. http://www.ncbi.nlm.nih.gov/entrez/query.fcgi?cmd=Ret rieve $\& \mathrm{db}=$ PubMed $\&$ dopt $=$ Citation $\&$ list uids $=10906546$

9. Liu, X.Q. and Y.H. Li, 2000. Epidemiological and nutritional research on prevention of cardiovascular disease in China. Br. J. Nutr., 84: S199-S203.

http://www.ncbi.nlm.nih.gov/entrez/query.fcgi?cmd=Ret rieve $\& \mathrm{db}=$ PubMed $\&$ dopt $=$ Citation $\&$ list uids $=11242470$

10. Barthwal, J., S. Nair and P. Kakkar, 2008. Heavy metal accumulation in medicinal plants collected from environmentally different sites. Biomed. Environ. Sci., 21: 319-324.

http://www.ncbi.nlm.nih.gov/entrez/query.fcgi?cmd=Ret rieve $\& \mathrm{db}=$ PubMed \&dopt $=$ Citation\&list uids $=18837296$

11. Ullah, M.F. and M.W. Khan, 2008. Food as medicine: Potential therapeutic tendencies of plant derived polyphenolic compounds. Asian Pac. J. Cancer Prev., 9: 187-196.

http://www.ncbi.nlm.nih.gov/entrez/query.fcgi? cmd=Ret rieve $\& \mathrm{db}=$ PubMed $\&$ dopt $=$ Citation $\&$ list uids $=18712957$

12. Krishnaswamy, K. and N. Raghuramulu, 1998. Bioactive phytochemicals with emphasis on dietary practices. Indian J. Med. Res., 108: 167-81. http://www.ncbi.nlm.nih.gov/entrez/query.fcgi?cmd=Ret rieve $\& \mathrm{db}=$ PubMed $\&$ dopt $=$ Citation\&list_uids $=9863273$

13. Arora, S., K. Kaur and S. Kaur, 2003. Indian medicinal plants as a reservoir of protective phytochemicals. Teratog. Carcinog. Mutagen., 1: 295-300. DOI: $10.1002 / \mathrm{tcm} .10055$

14. Krishnaswamy, K., 2008. Traditional Indian spices and their health significance. Asia Pacif. J. Clin. Nutr., 17: 265-268.

http://www.ncbi.nlm.nih.gov/entrez/query.fcgi?cm $\mathrm{d}=$ Retrieve\& $\mathrm{db}=$ PubMed\&dopt $=$ Citation\&list_uids $=18296352$

15. Ko, E., S. Rho, E.J. Lee, Y.H. Seo, C. Cho, Y. Lee, B.I. Min, M.K. Shin, M.C. Hong and H. Bae, 2004. Traditional Korean medicine (SCRT) modulate Th1/Th2 specific cytokine production in mice CD4+ T cell. J. Ethnopharmacol., 92: 121-128. DOI: $10.1016 /$ j.jep.2004.02.008

16. De La Barrera, E. and J.L. Andrade, 2005. Challenges to plant megadiversity: How environmental physiology can help. New Phytol., 167: 5-8. DOI: 10.1111/j.1469-8137.2005.01467.x

17. Wiart, C., E. Akaho, M. Hannah, M. Yassim, H. Hamimah, T.S. Au and M. Sulaiman, 2005. The rainforest of Southeast Asia, particularly Malaysia, is endowed with several medicinal plants species. Am. J. Chin. Med., 33: 683-685. http://www.ncbi.nlm.nih.gov/entrez/query.fcgi?cm $\mathrm{d}=$ Retrieve\& $\mathrm{db}=$ PubMed\&dopt $=$ Citation\&list_uids $=16173541$
18. Chang, Y.S. and Rasadah, M.A., 2004. Inventory, Documentation and Status of Medicinal Plants research in Malaysia. In: Medicinal Plants Research in Asia: The Framework and Project Workplans, Batugal, P.A., J. Kanniah, S.Y. Leeand and J.T. Oliver (Eds.). International Plant Genetic Resources Institute, pp: 120-126.

19. Arbec., 1998. Malaysia's national policy on biological diversity. http://www.arbec.com.my

20. Kulip, J., 2003. An ethnobotanical survey of medicinal and other useful plants of Murats in Sabah, Malaysia. Telopea, 10: 81-98. http://www.rbgsyd.nsw.gov.au/_data/assets/pdf_fi le/72710/Tel10Kul081.pdf

21. Lanfranco, G., 1992. Popular use of medicinal plants in the maltese islands. Insula, 1: 34-35.

22. Gonzalez-Tejero, M.R., M. Casares-Porcel, C.P. Sanchez-Rojas, J.M. Ramiro-Gutierrez, J. Molero-Mesa, A. Pieroni, M.E. Giusti, E. Censorii, C. De Pasquale, A. Della, D. ParaskevaHadijchambi, A. Hadjichambis, Z. Houmani, M. El-Demerdash, M. El-Zayat, M. Hmamouchi and S. Eljohrig, 2008. Medicinal plants in the Mediterranean area: Synthesis of the results of the project Rubia. J. Ethnopharmacol., 116: 341-357. DOI: 10.1016/j.jep.2007.11.045

23. Weeks, L.C. and T. Strudsholm, 2008. A scoping review of research on Complementary and Alternative Medicine (CAM) and the mass media: looking back, moving forward. BMC Complement. Altern. Med., 8: 43. DOI: 10.1186/1472-6882-8-43

24. WHO., 2003. Traditional Medicine: Fact Sheet. http://www.who.int/mediacentre/factsheets/fs134/en/

25. Sharma, Y.K. and K.R. Davis, 1997. The effects of ozone on antioxidant responses in plants. Free Radic. Biol. Med., 23: 480-488. http://www.ncbi.nlm.nih.gov/entrez/query.fcgi?cm $\mathrm{d}=$ Retrieve\& $\mathrm{db}=$ PubMed\&dopt $=$ Citation\&list_uids $=9214586$

26. Allen, R.D., R.P. Webb and S.A. Schake, 1997. Use of transgenic plants to study antioxidant defenses. Free Radic. Biol. Med., 23: 473-479. http://www.ncbi.nlm.nih.gov/entrez/query.fcgi?cm $\mathrm{d}=$ Retrieve\& $\mathrm{db}=$ PubMed\&dopt $=$ Citation\&list_uids $=9214585$

27. Chiang, Y.M., D.Y. Chuang, S.Y. Wang, Y.H. Kuo, P.W. Tsai and L.F. Shyur, 2004. Metabolite profiling and chemopreventive bioactivity of plant extracts from Bidens pilosa. J. Ethnopharmacol., 95: 409-419. DOI: 10.1016/j.jep.2004.08.010 
28. Xu, B. and S.K. Chang, 2008. Characterization of phenolic substances and antioxidant properties of food soybeans grown in the North DakotaMinnesota region. J. Agric. Food Chem., 56: 9102-9113. DOI: $10.1021 / \mathrm{jf} 801451 \mathrm{k}$

29. Bitsch, R., 1996. Pflanzenphenole und ihre gesundheitliche Wirkung. Naturw Rdsch. 49: 47-51.

30. Herrmann, K., 1994. In pflanzlichen Lebensmitteln vorkommende flavonoide als antioxidantien. Gordian, 93: 108-111. http://cat.inist.fr/?aModele $=$ afficheN\&cpsidt $=4919262$

31. Pratt, D., 1992. Natural Antioxidants not Exploited Commercially. In: Food Antioxidants. B.J.F. Hudson (Ed.). Elsevier Applied Science, USA., ISBN: 9781851664405, pp: 171-192.

32. Cook, N., 1996. Flavonoids-chemistry, metabolism, cardioprotective effect and dietary sources. Nutr. Biochem., 7: 66-76. http://cat.inist.fr/?aModele=afficheN\&cpsidt=3000741

33. Simonetti, P., C. Gardana and P. Pietta, 2001. Plasma levels of caffeic acid and antioxidant status after red wine intake. J. Agric. Food Chem., 49: 5964-5968.

http://www.ncbi.nlm.nih.gov/entrez/query.fcgi?cmd=Ret rieve $\& \mathrm{db}=$ PubMed $\&$ dopt $=$ Citation\&list_uids $=11743793$

34. Adedapo, A.A., F.O. Jimoh, A.J. Afolayan and P.J. Masika, 2008. Antioxidant activities and phenolic contents of the methanol extracts of the stems of Acokanthera oppositifolia and Adenia gummifera. BMC Complement. Altern. Med., 8: 54. http://www.ncbi.nlm.nih.gov/entrez/query.fcgi?cmd=Ret rieve $\& \mathrm{db}=$ PubMed $\&$ dopt $=$ Citation $\&$ list uids $=18817535$

35. Broncel, M., 2007. [Antiatherosclerotic properties of flavones from the roots of Scutellaria baicalensis Georgi]. Wiad Lek., 60: 294-7. http://www.ncbi.nlm.nih.gov/entrez/query.fcgi?cmd=Ret rieve $\& \mathrm{db}=$ PubMed $\&$ dopt $=$ Citation\&list uids $=1796689$

36. Vimala, S. and A. Mohd Ilham, 1999. Malaysian tropical forest medicinal plants: A source of natural antioxidants. J. Trop. For. Prod., 5: 32-38. http://direct.bl.uk/bld/PlaceOrder.do?UIN=063905 940\&ETOC $=$ RN\& from $=$ searchengine

37. Lu, F. and L. Foo, 1995. Phenolic Antioxidant Component of Evening Primrose. In: Nutrition, lipids, health and disease, Ong, A.S.H., E. Nikiand and L. Packer (Eds.). American Oil Chemists Society Press, Champaign, ISBN: 9780935315646.

38. Tsoyi, K., H.B. Park, Y.M. Kim, J.I. Chung, S.C. Shin, H.J. Shim, W.S. Lee, H.G. Seo, J.H. Lee, K.C. Chang and H.J. Kim, 2008. Protective effect of anthocyanins from black soybean seed coats on UVB-induced apoptotic cell death in vivo and in vivo. J. Agric. Food Chem., 55: 10600-10605. http://www.ncbi.nlm.nih.gov/entrez/query.fcgi?cmd=Ret rieve $\& \mathrm{db}=$ PubMed $\&$ dopt $=$ Citation\&list_uids $=18959412$
39. Ashraf, M., 2008. Biotechnological approach of improving plant salt tolerance using antioxidants as markers. Biotechnol. Adv., 27: 84-93. http://www.ncbi.nlm.nih.gov/entrez/query.fcgi?cmd=Ret rieve $\& \mathrm{db}=$ PubMed\&dopt $=$ Citation\&list_uids $=18950697$

40. Leutner, S., A. Eckert and W.E. Muller, 2001. ROS generation, lipid peroxidation and antioxidant enzyme activities in the aging brain. J. Neural Transm., 108: 955-967. http://www.ncbi.nlm.nih.gov/entrez/query.fcgi?cmd=Ret rieve $\& \mathrm{db}=$ PubMed $\&$ dopt $=$ Citation $\&$ list uids $=11716148$

41. Halliwell, B., 1994. Free radicals and antioxidants: A personal view. Nutr. Rev., 52: 253-265. http://www.ncbi.nlm.nih.gov/entrez/query.fcgi?cm $\mathrm{d}=$ Retrieve\& $\mathrm{db}=$ PubMed\&dopt $=$ Citation\&list_uids $=7970288$

42. Eberlein, M., K.A. Scheibner, K.E. Black, S.L. Collins, Y. Chan-Li, J.D. Powell and M.R. Horton, 2008. Anti-oxidant inhibition of hyaluronan fragmentinduced inflammatory gene expression. J. Inflamm. (Lond)., 5: 20.

http://www.ncbi.nlm.nih.gov/entrez/query.fcgi?cmd=Ret rieve $\& \mathrm{db}=$ PubMed $\&$ dopt $=$ Citation\&list_uids $=18986521$

43. Willet, W., 1994. Diet and health-what should we eat? Science, 264: 532-537. DOI: 10.1126/science.8160011

44. Vinson, J.A., Y.A. Dabbag, M.M. Serry and J. Jang, 1995. Plant flavonoids, especially tea flavonols, are powerful antioxidants using an in vivo oxidation model for heart disease. J. Agric. Food Chem., 43: 2800-2802.

http://cat.inist.fr/?aModele $=$ afficheN\&cpsidt $=2924226$

45. Yu, B.P., 1994. Cellular defenses against damage from reactive oxygen species. Physiol. Rev., 76: 139-162.

http://www.ncbi.nlm.nih.gov/entrez/query.fcgi?cm $\mathrm{d}=$ Retrieve $\& \mathrm{db}=$ PubMed\&dopt $=$ Citation\&list_uids $=8295932$

46. Ames, B.M., M.K. Shigena and T.M. Hagen, 1993. Oxidants, antioxidants and the degenerative diseases of aging. Proc. Natl. Acad. Sci. USA., 90: 7915-7922. http://www.pnas.org/content/90/17/7915.full.pdf + html

47. Lampe, J.W., 1999. Health effects of vegetables and fruits: Assessing mechanisms of action in human experimental studies. Am. J. Clin. Nutr., 70: 475S-490S. http://www.ajcn.org/cgi/content/full/70/3/475S

48. Ames, B.N., 1998. Micronutrients prevent cancer and delay aging. Toxicol. Lett., 102-103: 5-18. http://www.ncbi.nlm.nih.gov/entrez/query.fcgi?cm $\mathrm{d}=$ Retrieve\& $\mathrm{db}=$ PubMed\&dopt $=$ Citation\&list_uids $=10022226$ 
49. Baghurst, K.I., A.A. Hertzler, S.J. Record and C. Spurr, 1992. The development of a simple diatary assessment and educational tool for use by individuals and nutrition educators. J. Nutr. Educ., 24: $165-172$.

http://grande.nal.usda.gov/ibids/index.php?mode2= detail\&origin $=$ ibids_references\&therow $=435760$

50. Rohana, S., S. Vimala, A.A. Rashih and A.M. Ilham, 2002. Engkabang (Shorea macrophylla): antioxidant evaluation. Proceedings of the Seminar on Medicinal and Aromatic Plants-Towards Modernisation of Research and Technologies in Herbal Industries, July 24-25, Kuala Lumpur: Forest Research Institute Malaysia, pp: 120-123. http://www.cababstractsplus.org/abstracts/Abstract. aspx?AcNo=20033046906

51. Vimala, S., A. Mohd. Ilham, A. Abdull Rashih and S. Rohana, 2003. Natural Antioxidants: Piper sarmentosum (Kadok) and Morinda elliptica (Mengkudu). Mal. J. Nutr., 9: 41-51.

ISSN: 1394-035X

http://nutriweb.org.my/publications/mjn009_1/mjn 9n1_art5.pdf

52. Zin, Z.M., A. Abdul-Hamid and A. Osman, 2002. Antioxidative activity of extracts from Mengkudu (Morinda citrifolia L.) root, fruit and leaf. Food Chem., 78: 227-231. DOI: S0308-8146(01)00402-2

53. Zin, Z.M., A. Abdul-Hamid, A. Osman and N. Saari, 2006. Antioxidative activities of chromatographic fractions obtained from root, fruit and leaf of Mengkudu (Morinda citrifolia L.). Food Chem., 94: 169-178. DOI: 10.1016/j.foodchem.2004.08.048

54. Cho, E.J., T. Yokozawa, D.Y. Rhyu, S.C. Kim, N. Shibahara and J.C. Park, 2003. Study on the inhibitory effects of Korean medicinal plants and their main compounds on the 1,1-diphenyl-2picrylhydrazyl radical. Phytomedicine, 10: 544-51. http://www.ncbi.nlm.nih.gov/entrez/query.fcgi?cm $\mathrm{d}=$ Retrieve\& $\mathrm{db}=$ PubMed\&dopt $=$ Citation\&list_uids $=13678241$

55. Krishnaiah, D., R. Sarbatly and A. Bono, 2007. Phytochemical antioxidants for health and medicine -A move towards nature. Biotechnol. Mol. Biol. Rev., 1: 97-104. http://www.academicjournals.org/BMBR

56. Kumari, A. and P. Kakkar, 2008. Screening of antioxidant potential of selected barks of Indian medicinal plants by multiple in vivo assays. Biomed. Environ. Sci., 21: 24-9. http://www.ncbi.nlm.nih.gov/entrez/query.fcgi?cm $\mathrm{d}=$ Retrieve $\& \mathrm{db}=$ PubMed\&dopt $=$ Citation\&list uids $=18478975$
57. Shan, B., Y.Z. Cai, M. Sun and H. Corke, 2005. Antioxidant capacity of 26 spice extracts and characterization of their phenolic constituents. J. Agric. Food Chem., 53: 7749-59. DOI: 10.1021/jf051513y

58. Shobana, S. and K.A. Naidu, 2000. Antioxidant activity of selected Indian spices. Prostaglandins Leukot Essent Fatty Acids, 62: 107-110. http://www.ncbi.nlm.nih.gov/entrez/query.fcgi?cm $\mathrm{d}=$ Retrieve\&db=PubMed\&dopt $=$ Citation\&list_uids $=10780875$

59. Jessie, S.W. and T.P. Krishnakantha, 2005. Inhibition of human platelet aggregation and membrane lipid peroxidation by food spice, saffron. Mol. Cell Biochem., 278: 59-63. DOI: 10.1007/s11010-005-5155-9

60. Tapsell, L.C., I. Hemphill, L. Cobiac, C.S. Patch, D.R. Sullivan, M. Fenech, S. Roodenrys, J.B. Keogh, P.M. Clifton, P.G. Williams, V.A. Fazio and K.E. Inge, 2006. Health benefits of herbs and spices: the past, the present, the future. Med. J. Aust., 185: S4-S24. http://www.ncbi.nlm.nih.gov/entrez/query.fcgi?cm $\mathrm{d}=$ Retrieve $\& \mathrm{db}=$ PubMed\&dopt $=$ Citation\&list_uids $=17022438$

61. Craig, W.J., 1999. Health-promoting properties of common herbs. Am. J. Clin. Nutr., 70: 491S-499S. http://www.ncbi.nlm.nih.gov/entrez/query.fcgi?cmd=Ret rieve $\& \mathrm{db}=$ PubMed $\&$ dopt $=$ Citation\&list_uids $=10479221$

62. Nakatani, N., 2000. Phenolic antioxidants from herbs and spices. Biofactors, 13: 141-146. http://www.ncbi.nlm.nih.gov/entrez/query.fcgi?cm $\mathrm{d}=$ Retrieve\& $\mathrm{db}=$ PubMed\&dopt $=$ Citation\&list_uids $=11237173$

63. Shanmugasundaram, K.R., S. Ramanujam and E.R. Shanmugasundaram, 1994. Amrita Bindu--a salt-spice-herbal health food supplement for the prevention of nitrosamine induced depletion of antioxidants. J. Ethnopharmacol., 42: 83-93. http://www.ncbi.nlm.nih.gov/entrez/query.fcgi?cmd=Ret rieve $\& \mathrm{db}=$ PubMed\&dopt $=$ Citation\&list_uids $=\mathbf{8 0 7 2 3 0 8}$

64. Lojek, A., J. Pecivova, T. Macickova, R. Nosal, I. Papezikova and M. Ciz, 2008. Effect of carvedilol on the production of reactive oxygen species by HL60 cells. Neuro Endocrinol. Lett., 29: 779-783. http://www.ncbi.nlm.nih.gov/entrez/query.fcgi?cm $\mathrm{d}=$ Retrieve\& $\mathrm{db}=$ PubMed\&dopt $=$ Citation\&list_uids $=18987604$

65. Li, Z.L., Q.L. Lin, R.J. Liu, W.Y. Xie and W.F. Xiao, 2007. [Reducing oxidative DNA damage by adding antioxidants in human semen samples undergoing cryopreservation procedure]. Zhonghua Yi Xue Za Zhi., 87: 3174-7.

http://www.ncbi.nlm.nih.gov/entrez/query.fcgi? $\mathrm{cmd}=$ Ret rieve $\& d b=$ PubMed $\&$ dopt $=$ Citation $\&$ list_uids $=18399108$ 
66. Devasagayam, T.P. and K.B. Sainis, 2002. Immune system and antioxidants, especially those derived from Indian medicinal plants. Indian J. Exp. Biol., 40: 639-655.

http://www.ncbi.nlm.nih.gov/entrez/query.fcgi?cmd=Ret rieve \&db=PubMed\&dopt $=$ Citation\&list_uids $=12587713$

67. Delgado, M.E., A.I. Haza, N. Arranz, A. Garcia and P. Morales, 2008. Dietary polyphenols protect against N-nitrosamines and benzo(a)pyreneinduced DNA damage (strand breaks and oxidized purines/pyrimidines) in HepG2 human hepatoma cells. Eur. J. Nutr., 47: 479-490. http://www.ncbi.nlm.nih.gov/entrez/query.fcgi?cm $\mathrm{d}=$ Retrieve\& $\mathrm{db}=$ PubMed\&dopt $=$ Citation\&list_uids $=18974940$

68. Jagetia, G.C. and B.B. Aggarwal, 2007. Spicing up of the immune system by curcumin. J. Clin. Immunol., 27: 19-35. http://www.ncbi.nlm.nih.gov/entrez/query.fcgi?cmd=Ret rieve $\& \mathrm{db}=$ PubMed $\&$ dopt $=$ Citation\&list_uids $=17211725$

69. Tilak, J.C., M. Banerjee, H. Mohan and T.P. Devasagayam, 2004. Antioxidant availability of turmeric in relation to its medicinal and culinary uses. Phytother. Res., 18: 798-804. DOI: 10.1002/ptr.1553

70. Arora, R.B., V. Kapoor, N. Basu and A.P. Jain, 1971. Anti-inflammatory studies on Curcuma longa (turmeric). Indian J. Med. Res., 59: 1289-95. http://www.ncbi.nlm.nih.gov/entrez/query.fcgi?cmd=Ret rieve $\& \mathrm{db}=$ PubMed\&dopt $=$ Citation\&list_uids $=5132235$

71. Suryanarayana, P., A. Satyanarayana, N. Balakrishna, P.U. Kumar and G.B. Reddy, 2007. Effect of turmeric and curcumin on oxidative stress and antioxidant enzymes in streptozotocin-induced diabetic rat. Med. Sci. Monitor., 13: BR286-BR292. http://www.ncbi.nlm.nih.gov/entrez/query.fcgi?cm $\mathrm{d}=$ Retrieve\& $\mathrm{db}=$ PubMed\&dopt $=$ Citation\&list_uids $=18049430$

72. Araujo, C.C. and L.L. Leon, 2001. Biological activities of Curcuma longa L. Mem. Inst. Oswaldo Cruz., 96: 723-728. http://www.ncbi.nlm.nih.gov/entrez/query.fcgi?cm $\mathrm{d}=$ Retrieve $\& \mathrm{db}=$ PubMed\&dopt $=$ Citation\&list_uids $=11500779$

73. Aggarwal, B.B. and K.B. Harikumar, 2008. Potential therapeutic effects of curcumin, the antiinflammatory agent, against neurodegenerative, cardiovascular, pulmonary, metabolic, autoimmune and neoplastic diseases. Int. J. Biochem. Cell Biol., DOI: 10.1016/j.biocel.2008.06.010

74. Pari, L., D. Tewas and J. Eckel, 2008. Role of curcumin in health and disease. Arch. Physiol. Biochem., 114: 127-49. DOI: $10.1080 / 13813450802033958$
75. Surh, Y.J. and K.S. Chun, 2007. Cancer chemopreventive effects of curcumin. Adv. Exp. Med. Biol., 595: 149-172.

http://www.ncbi.nlm.nih.gov/entrez/query.fcgi?cmd=Ret rieve $\& \mathrm{db}=$ PubMed $\&$ dopt $=$ Citation\&list_uids $=17569209$

76. Shishodia, S., M.M. Chaturvedi and B.B. Aggarwal, 2007. Role of curcumin in cancer therapy. Curr. Probl. Cancer, 31: 243-305. DOI: 10.1016/j.currproblcancer.2007.04.001

77. Chan, M.M., H.I. Huang, M.R. Fenton and D. Fong, 1998. In vivo inhibition of nitric oxide synthase gene expression by curcumin, a cancer preventive natural product with anti-inflammatory properties. Biochem. Pharmacol., 55: 1955-1962. http://www.ncbi.nlm.nih.gov/entrez/query.fcgi? cmd=Ret rieve $\& \mathrm{db}=$ PubMed \&dopt=Citation $\&$ list_uids $=9714315$

78. Varalakshmi, C., A.M. Ali, B.V. Pardhasaradhi, R.M. Srivastava, S. Singh and A. Khar, 2008. Immunomodulatory effects of curcumin: In vivo. Int. Immunopharmacol., 8: 688-700. DOI: 10.1016/j.intimp.2008.01.008

79. Xiang, Y.Z., H.C. Shang, X.M. Gao and B.L. Zhang, 2008. A comparison of the ancient use of ginseng in traditional Chinese medicine with modern pharmacological experiments and clinical trials. Phytother. Res., 22: 851-858. DOI: 10.1002/ptr.2384

80. Hwang, J.T., M.S. Lee, H.J. Kim, M.J. Sung, H.Y. Kim, M.S. Kim and D.Y. Kwon, 2008. Antiobesity effect of ginsenoside $\operatorname{Rg} 3$ involves the AMPK and PPAR-gamma signal pathways. Phytother. Res., 23: 262-266.

http://www.ncbi.nlm.nih.gov/entrez/query.fcgi?cm $\mathrm{d}=$ Retrieve\& $\mathrm{db}=$ PubMed\&dopt $=$ Citation\&list_uids $=18844326$

81. Xu, T.M., M.H. Cui, Y. Xin, L.P. Gu, X. Jiang, M.M. Su, D.D. Wang and W.J. Wang, 2008. Inhibitory effect of ginsenoside $\mathrm{Rg} 3$ on ovarian cancer metastasis. Chin. Med. J. (Engl.), 121: 1394-1397. http:/www.ncbi.nlm.nih.gov/entrez/query.fcgi?cm $\mathrm{d}=$ Retrieve\& $\mathrm{db}=$ PubMed\&dopt $=$ Citation\&list_uids $=18959116$

82. Lee, J.H., J.H. Lee, Y.M. Lee, P.N. Kim and C.S. Jeong, 2008. Potential analgesic and anti-inflammatory activities of Panax ginseng head butanolic fraction in animals. Food Chem. Toxicol., 46: 3749-3752. http://www.ncbi.nlm.nih.gov/entrez/query.fcgi?cm $\mathrm{d}=$ Retrieve \& $\mathrm{db}=$ PubMed\&dopt $=$ Citation\&list_uids $=18930781$

83. Gupta, Y.K., M. Sharma and G. Chaudhary, 2001. Antiepileptic activity of Panax ginseng against pentylenetetrazole induced kindling in rats. Indian J. Physiol. Pharmacol., 45: 502-506. http://www.ncbi.nlm.nih.gov/entrez/query.fcgi?cmd=Ret rieve $\& \mathrm{db}=$ PubMed\&dopt $=$ Citation\&list_uids $=11883161$ 
84. Reay, J.L., D.O. Kennedy and A.B. Scholey, 2006. Effects of Panax ginseng, consumed with and without glucose, on blood glucose levels and cognitive performance during sustained 'mentally demanding' tasks. J. Psychopharmacol., 20: 771-781. DOI: $10.1177 / 0269881106061516$

85. Reay, J.L., D.O. Kennedy and A.B. Scholey, 2005. Single doses of Panax ginseng (G115) reduce blood glucose levels and improve cognitive performance during sustained mental activity. J. Psychopharmacol., 19: 357-365. DOI: 10.1177/0269881105053286

86. Furukawa, T., C.X. Bai, A. Kaihara, E. Ozaki, T. Kawano, Y. Nakaya, M. Awais, M. Sato, Y. Umezawa and J. Kurokawa, 2006. Ginsenoside Re, a main phytosterol of Panax ginseng, activates cardiac potassium channels via a nongenomic pathway of sex hormones. Mol. Pharmacol., 70: 1916-1924. DOI: $10.1124 / \mathrm{mol} .106 .028134$

87. Radad, K., G. Gille, L. Liu and W.D. Rausch, 2006. Use of ginseng in medicine with emphasis on neurodegenerative disorders. J. Pharmacol. Sci., 100: $175-186$.

http://www.ncbi.nlm.nih.gov/entrez/query.fcgi?cm $\mathrm{d}=$ Retrieve\& $\mathrm{db}=$ PubMed\&dopt $=$ Citation\&list_uids $=16518078$

88. Maurya, D.K., T.P. Devasagayam and C.K. Nair, 2006. Some novel approaches for radioprotection and the beneficial effect of natural products. Indian J. Exp. Biol., 44: 93-114. http://www.ncbi.nlm.nih.gov/entrez/query.fcgi?cm $\mathrm{d}=$ Retrieve $\& \mathrm{db}=$ PubMed\&dopt $=$ Citation\&list_uids $=16480175$

89. Arora, R., D. Gupta, R. Chawla, R. Sagar, A. Sharma, R. Kumar, J. Prasad, S. Singh, N. Samanta and R.K. Sharma, 2005. Radioprotection by plant products: Present status and future prospects. Phytother. $\quad$ Res., 19 : 1-22. http://www.ncbi.nlm.nih.gov/entrez/query.fcgi?cm $\mathrm{d}=$ Retrieve\& $\mathrm{db}=$ PubMed\&dopt $=$ Citation\&list_uids $=15799007$

90. Vasin, M.V., I.B. Ushakov, V. Kovtun, S.N. Komarova, L.A. Semenova and A.A. Galkin, 2004. Comparative effectiveness of antioxidant melatonin and radioprotectors indralin and phenylephrine in local radiation injuries]. Radiat. Biol. $\quad$ Radioecol., 44 : 68-71. http://www.ncbi.nlm.nih.gov/entrez/query.fcgi?cmd=Ret rieve $\& \mathrm{db}=$ PubMed $\&$ dopt $=$ Citation $\&$ list uids $=15060944$

91. Weiss, J.F. and M.R. Landauer, 2003. Protection against ionizing radiation by antioxidant nutrients and phytochemicals. Toxicology, 189: 1-20. http://www.ncbi.nlm.nih.gov/entrez/query.fcgi? $\mathrm{cmd}=$ Ret rieve $\& \mathrm{db}=$ PubMed $\&$ dopt $=$ Citation $\&$ list uids $=12821279$
92. Naik, G.H., K.I. Priyadarsini, D.B. Naik, R. Gangabhagirathi and H. Mohan, 2004. Studies on the aqueous extract of Terminalia chebula as a potent antioxidant and a probable radioprotector. Phytomedicine, 11: 530-538.

http://www.ncbi.nlm.nih.gov/entrez/query.fcgi?cm $\mathrm{d}=$ Retrieve \& $\mathrm{db}=$ PubMed\&dopt $=$ Citation\&list_uids $=15500265$

93. Shirazi, A., G. Ghobadi and M. Ghazi-Khansari, 2007. A radiobiological review on melatonin: A novel radioprotector. J. Radiat. Res. (Tokyo), 48: 263-272. http://www.ncbi.nlm.nih.gov/entrez/query.fcgi?cmd=Ret rieve $\& d b=$ PubMed\&dopt $=$ Citation\&list_uids $=17641465$

94. Dittmann, K., C. Mayer, G. Wanner, R. Kehlbach and H.P. Rodemann, 2007. The radioprotector Ophospho-tyrosine stimulates DNA-repair via epidermal growth factor receptor- and DNAdependent kinase phosphorylation. Radiother. Oncol., 84: 328-334. DOI: 10.1016/j.radonc.2007.07.006

95. Kim, I.G. and T.J. Oh, 2000. 2Mercaptoethylamine, radioprotector, inhibits the induction of the oxidative stress-inducible (soi) gene by paraquat in Escherichia coli. Pharmacol. Res., 42: 429-433. DOI: 10.1006/phrs.2000.0708

96. Veerapur, V.P., K.R. Prabhakar, V.K. Parihar, M.R. Kandadi, S. Ramakrishana, B. Mishra, B.S. Rao, K.K. Srinivasan, K.I. Priyadarsini and M.K. Unnikrishnan, 2007. Ficus racemosa stem bark extract: A potent antioxidant and a probable natural radioprotector. Evid. Based Complement. Alternat. Med., 1: 1-8. DOI: 10.1093/ecam/nem119

97. Haksar, A., A. Sharma, R. Chawla, R. Kumar, R. Arora, S. Singh, J. Prasad, M. Gupta, R.P. Tripathi, M.P. Arora, F. Islam and R.K. Sharma, 2006. Zingiber officinale exhibits behavioral radioprotection against radiation-induced CTA in a gender-specific manner. Pharmacol. Biochem. Behav., 84: 179-188. http://www.ncbi.nlm.nih.gov/entrez/query.fcgi?cm $\mathrm{d}=$ Retrieve $\& \mathrm{db}=$ PubMed\&dopt $=$ Citation\&list_uids $=16797061$

98. Jindal, A., D. Soyal, G. Sancheti and P.K. Goyal, 2006. Radioprotective potential of Rosemarinus officinalis against lethal effects of gamma radiation: A preliminary study. J. Environ. Pathol. Toxicol. Oncol., 25: 633-642.

http://www.ncbi.nlm.nih.gov/entrez/query.fcgi?cm $\mathrm{d}=$ Retrieve $\& \mathrm{db}=$ PubMed\&dopt $=$ Citation\&list uids $=17341204$

99. Ching, L.S. and S. Mohamed, 2001. Alphatocopherol content in 62 edible tropical plants. J. Agric. Food Chem., 49: 3101-3105. http://www.ncbi.nlm.nih.gov/entrez/query.fcgi?cmd=Ret rieve $\& \mathrm{db}=$ PubMed $\&$ dopt $=$ Citation\&list $\_$uids $=11410015$ 
100.Miean, K.H. and S. Mohamed, 2001. Flavonoid (Myricetin, Quercetin, Kaempferol, Luteolin and Apigenin) content of edible tropical plants. J. Agric. Food Chem., 49: 3106-3112. http://www.ncbi.nlm.nih.gov/entrez/query.fcgi?cmd=Ret rieve $\& \mathrm{db}=$ PubMed\&dopt $=$ Citation\&list_uids $=11410016$

101.Gupta, S. and J. Prakash, 2008. Studies on Indian green leafy vegetables for their antioxidant activity. Plant Foods Hum. Nutr., 64: 39-45. DOI: 10.1007/s11130-008-0096-6

102.Zeashan, H., G. Amresh, S. Singh and C.V. Rao, 2008. Hepatoprotective activity of Amaranthus spinosus in experimental animals. Food Chem. Toxicol., 46: 3417-21. DOI: 10.1016/j.fct.2008.08.013

103.Lin, B.F., B.L. Chiang and J.Y. Lin, 2005. Amaranthus spinosus water extract directly stimulates proliferation of B lymphocytes in vivo. Int. Immunopharmacol., 5: 711-722. DOI: 10.1016/j.intimp.2004.12.001

104.Salleh, M.N., I. Runnie, P.D. Roach, S. Mohamed and M.Y. Abeywardena, 2002. Inhibition of lowdensity lipoprotein oxidation and up-regulation of low-density lipoprotein receptor in HepG 2 cells by tropical plant extracts. J. Agric. Food Chem., 50: 3693-3697.

http://www.ncbi.nlm.nih.gov/entrez/query.fcgi?cmd=Ret rieve $\& \mathrm{db}=$ PubMed $\&$ dopt $=$ Citation\&list_uids $=12059144$

105.Gopi, R., C.A. Jaleel, R. Sairam, G.M. Lakshmanan, M. Gomathinayagam and R. Panneerselvam, 2007. Differential effects of hexaconazole and paclobutrazol on biomass, electrolyte leakage, lipid peroxidation and antioxidant potential of Daucus carota L. Colloid. Surf. B. Biointerface., 60: 180-186. DOI: 10.1016/j.colsurfb.2007.06.003

106.Ravindra, P.V. and M.S. Narayan, 2003. Antioxidant activity of the anthocyanin from carrot (Daucus carota) callus culture. Int. J. Food Sci. Nutr., 54: 349-355. $10.1080 / 09637480120092134$

107.Abeywardena, M., I. Runnie, M. Nizar, S. Momamed and R. Head, 2002. Polyphenol-enriched extract of oil palm fronds (Elaeis guineensis) promotes vascular relaxation via endothelium-dependent mechanisms. Asia Pacif. J. Clin. Nutr., 11: S467-S472. http://www.ncbi.nlm.nih.gov/entrez/query.fcgi?cmd=Ret rieve $\& \mathrm{db}=$ PubMed $\&$ dopt $=$ Citation $\&$ list uids $=12492636$

108.Rahmat, A., V. Kumar, L.M. Fong, S. Endrini and H.A. Sani, 2004. Determination of total antioxidant activity in three types of local vegetables shoots and the cytotoxic effect of their ethanolic extracts against different cancer cell lines. Asia Pacif. J. Clin. Nutr., 13: 308-311.

http://www.ncbi.nlm.nih.gov/entrez/query.fcgi? $\mathrm{cmd}=$ Ret rieve $\& \mathrm{db}=$ PubMed $\&$ dopt $=$ Citation\&list_uids $=15331345$
109.Misra, S., R.K. Maikhuri, C.P. Kala, K.S. Rao and K.G. Saxena, 2008. Wild leafy vegetables: a study of their subsistence dietetic support to the inhabitants of Nanda Devi Biosphere Reserve, India. J. Ethnobiol. Ethnomed., 4: 15. DOI: 10.1186/1746-4269-4-15

110.Lin, P. and T.B. Ng, 2008. A novel and exploitable antifungal peptide from kale (Brassica alboglabra) seeds. Peptides, 29: 1664-1671. DOI: 10.1016/j.peptides.2008.05.020

111.Takaya, Y., Y. Kondo, T. Furukawa and M. Niwa, 2003. Antioxidant constituents of radish sprout (Kaiware-daikon), Raphanus sativus L. J. Agric. Food Chem., 51: 8061-8066. DOI: 10.1021/jf0346206

112.Runnie, I., M.N. Salleh, S. Mohamed, R.J. Headb and M.Y. Abeywardena, 2004. Vasorelaxation induced by common edible tropical plant extracts in isolated rat aorta and mesenteric vascular bed. J. Ethnopharmacol., 92: 311-316. DOI: 10.1016/j.jep.2004.03.019

113.Mackeen, M.M., A.M. Ali, N.H. Lajis, K. Kawazu, Z. Hassan, M. Amran, M. Habsah, L.Y. Mooi and S.M. Mohamed, 2000. Antimicrobial, antioxidant, antitumour-promoting and cytotoxic activities of different plant part extracts of Garcinia atroviridis Griff ex T. Anders. J. Ethnopharmacol., 72: 395-402. http://www.ncbi.nlm.nih.gov/entrez/query.fcgi?cmd=Ret rieve $\& \mathrm{db}=$ PubMed\&dopt $=$ Citation\&list_uids $=10996278$

114.Permana, D., N.H. Lajis, M.M. Mackeen, A.M. Ali, N. Aimi, M. Kitajima and H. Takayama, 2001. Isolation and bioactivities of constituents of the roots of Garcinia atroviridis. J. Nat. Prod., 64: 976-979. http://www.ncbi.nlm.nih.gov/entrez/query.fcgi?cm $\mathrm{d}=$ Retrieve\& $\mathrm{db}=$ PubMed\&dopt $=$ Citation\&list_uids $=11473441$

115.Priyadarshani, A.M. and U.G. Chandrika, 2007. Content and in-vitro accessibility of pro-vitamin A carotenoids from Sri Lankan cooked non-leafy vegetables and their estimated contribution to vitamin A requirement. Int. J. Food Sci. Nutr., 58: 659-667. DOI: 10.1080/09637480701395580

116.Maoka, T., N. Akimoto, K. Ishiguro, M. Yoshinaga and M. Yoshimoto, 2007. Carotenoids with a 5,6dihydro-5,6-dihydroxy-beta-end group, from yellow sweet potato "Benimasari", Ipomoea batatas Lam. Phytochemistry, 68: 1740-1745. DOI: 10.1016/j.phytochem.2007.03.019

117.Huang, G.J., M.J. Sheu, H.J. Chen, Y.S. Chang and Y.H. Lin, 2007. Inhibition of reactive nitrogen species in vivo and ex vivo by trypsin inhibitor from sweet potato 'Tainong 57' storage roots. J. Agric. Food Chem., 55: 6000-6006. DOI: $10.1021 / \mathrm{jf0701786}$ 
118.Han, K.H., A. Matsumoto, K. Shimada, M. Sekikawa and M. Fukushima, 2007. Effects of anthocyaninrich purple potato flakes on antioxidant status in F344 rats fed a cholesterol-rich diet. Br. J. Nutr., 98: 914-921. DOI: 10.1017/S0007114507761792

119.Dini, I., G.C. Tenore and A. Dini, 2006. New polyphenol derivative in Ipomoea batatas tubers and its antioxidant activity. J. Agric. Food Chem., 54: 8733-8737. DOI: $10.1021 / \mathrm{jf061687v}$

120.Ansari, N.M., L. Houlihan, B. Hussain and A. Pieroni, 2005. Antioxidant activity of five vegetables traditionally consumed by South-Asian migrants in Bradford, Yorkshire, UK. Phytother. Res., 19: 907-911. DOI: 10.1002/ptr.1756

121.Chandra, A., A.A. Mahdi, R.K. Singh, F. Mahdi and R. Chander, 2008. Effect of Indian herbal hypoglycemic agents on antioxidant capacity and trace elements content in diabetic rats. J. Med. Food, 11: 506-512. DOI: 10.1089/jmf.2007.0042

122.Saxena, R., K. Venkaiah, P. Anitha, L. Venu and M. Raghunath, 2007. Antioxidant activity of commonly consumed plant foods of India: Contribution of their phenolic content. Int. J. Food Sci. Nutr., 58: 250-260. DOI: 10.1080/09637480601121953

123.Sathishsekar, D. and S. Subramanian, 2005. Antioxidant properties of Momordica Charantia (bitter gourd) seeds on Streptozotocin induced diabetic rats. Asia Pacif. J. Clin. Nutr., 14: 153-158. http://www.ncbi.nlm.nih.gov/entrez/query.fcgi?cmd=Ret rieve $\& \mathrm{db}=$ PubMed\&dopt $=$ Citation\&list_uids $=15927932$

124.Jagetia, G.C. and M.S. Baliga, 2004. The evaluation of nitric oxide scavenging activity of certain Indian medicinal plants in vivo: A preliminary study. J. Med. Food, 7: 343-348. DOI: $10.1089 / 1096620041938740$

125.Nguyen-Pouplin, J., H. Tran, H. Tran, T.A. Phan, C. Dolecek, J. Farrar, T.H. Tran, P. Caron, B. Bodo and P. Grellier, 2007. Antimalarial and cytotoxic activities of ethnopharmacologically selected medicinal plants from South Vietnam. J. Ethnopharmacol., 109: 417-427. DOI: 10.1016/j.jep.2006.08.011

126.Xu, B.J., S.H. Yuan and S.K. Chang, 2007. Comparative studies on the antioxidant activities of nine common food legumes against copper-induced human low-density lipoprotein oxidation in vivo. J. Food Sci., 72: S522-S527. DOI: 10.1111/j.17503841.2007.00464.x

127.Lee, J.H., B.W. Lee, J.H. Kim, T.S. Jeong, M.J. Kim, W.S. Lee and K.H. Park, 2006. LDL-antioxidant pterocarpans from roots of Glycine max (L.) Merr. J. Agric. Food Chem., 54: 2057-2063. DOI: $10.1021 /$ jf052431c
128.Batish, D.R., H.P. Singh, N. Setia, S. Kaur and R.K. Kohli, 2006. 2-Benzoxazolinone (BOA) induced oxidative stress, lipid peroxidation and changes in some antioxidant enzyme activities in mung bean (Phaseolus aureus). Plant Physiol. Biochem., 44: 819-827. DOI: 10.1016/j.plaphy.2006.10.014

129.Jiratanan, T. and R.H. Liu, 2004. Antioxidant activity of processed table beets (Beta vulgaris var, conditiva) and green beans (Phaseolus vulgaris L.). J. Agric. Food Chem., 52: 2659-2670. DOI: $10.1021 / \mathrm{jf034861 \textrm {d }}$

130.Venkateswaran, S., L. Pari and G. Saravanan, 2002. Effect of Phaseolus vulgaris on circulatory antioxidants and lipids in rats with streptozotocininduced diabetes. J. Med. Food., 5: 97-103. DOI: $10.1089 / 109662002760178186$

131. Wojtyla, L., M. Garnczarska, T. Zalewski, W. Bednarski, L. Ratajczak and S. Jurga, 2006. A comparative study of water distribution, free radical production and activation of antioxidative metabolism in germinating pea seeds. J. Plant Physiol., 163: 12071220. DOI: 10.1016/j.jplph.2006.06.014

132.Chang, Q. and Y.S. Wong, 2004. Identification of flavonoids in Hakmeitau beans (Vigna sinensis) by high-performance liquid chromatographyelectrospray mass spectrometry (LC-ESI/MS). J. Agric. Food Chem., 52: 6694-6699. DOI: 10.1021/jf049114a

133.Subban, R., A. Veerakumar, R. Manimaran, K.M. Hashim and I. Balachandran, 2008. Two new flavonoids from Centella asiatica (Linn.). Nat. Med. (Tokyo), 62: 369-373. DOI: 10.1007/s11418008-0229-0

134. Shinomol, G.K. and Muralidhara, 2008. Effect of Centella asiatica leaf powder on oxidative markers in brain regions of prepubertal mice in vivo and its in vivo efficacy to ameliorate 3-NPA-induced oxidative stress in mitochondria. Phytomedicine, 15: 971-984. DOI: 10.1016/j.phymed.2008.04.010

135.Saha, K., N.H. Lajis, D.A. Israf, A.S. Hamzah, S. Khozirah, S. Khamis and A. Syahida, 2004. Evaluation of antioxidant and nitric oxide inhibitory activities of selected Malaysian medicinal plants. J. Ethnopharmacol., 92: 263-267. DOI: 10.1016/j.jep.2004.03.007

136. Arivazhagan, S., B. Velmurugan, V. Bhuvaneswari and S. Nagini, 2004. Effects of aqueous extracts of garlic (Allium sativum) and neem (Azadirachta indica) leaf on hepatic and blood oxidant-antioxidant status during experimental gastric carcinogenesis. J. Med. Food, 7: 33433-9. DOI: $10.1089 / 1096620041938731$ 
137.Saravanan, G. and J. Prakash, 2004. Effect of garlic (Allium sativum) on lipid peroxidation in experimental myocardial infarction in rats. J. Ethnopharmacol., 94: 155-158. DOI: 10.1016/j.jep.2004.04.029

138. Shui, G. and L.L. Peng, 2004. An improved method for the analysis of major antioxidants of Hibiscus esculentus Linn. J. Chromatogr. A., 1048: 17-24.

$\mathrm{http} / /$ www.ncbi.nlm.nih.gov/entrez/query.fcgi?cmd=Ret rieve $\& \mathrm{db}=$ PubMed $\& \mathrm{dopt}=$ Citation $\&$ list uids $=15453414$

139.Mohan Kumar, M., M.C. Joshi, T. Prabha, M. Dorababu and R.K. Goel, 2006. Effect of plantain banana on gastric ulceration in NIDDM rats: Role of gastric mucosal glycoproteins, cell proliferation, antioxidants and free radicals. Indian J. Exp. Biol., 44: 292-299.

http://www.ncbi.nlm.nih.gov/entrez/query.fcgi?cmd=Ret rieve $\& \mathrm{db}=$ PubMed $\&$ dopt $=$ Citation\&list uids $=16629371$

140.Dhanabal, S.P., M. Sureshkumar, M. Ramanathan and B. Suresh, 2005. Hypoglycemic effect of ethanolic extract of Musa sapientum on alloxan induced diabetes mellitus in rats and its relation with antioxidant potential. J. Herb. Pharmacother., 5: 7-19.

http://www.ncbi.nlm.nih.gov/entrez/query.fcgi?cm $\mathrm{d}=$ Retrieve \& $\mathrm{db}=$ PubMed\&dopt $=$ Citation\&list_uids $=16260406$

141.Goel, R.K., K. Sairam and C.V. Rao, 2001. Role of gastric antioxidant and anti-Helicobactor pylori activities in antiulcerogenic activity of plantain banana (Musa sapientum var. paradisiaca). Indian J. Exp. Biol., 39: 719-722. http://www.ncbi.nlm.nih.gov/entrez/query.fcgi?cmd=Ret rieve $\& \mathrm{db}=$ PubMed $\&$ dopt $=$ Citation\&list_uids $=12019769$

142.Qian, H. and V. Nihorimbere, 2004. Antioxidant power of phytochemicals from Psidium guajava leaf. J. Zhejiang Univ. Sci., 5: 676-683. http://www.ncbi.nlm.nih.gov/entrez/query.fcgi?cmd=Ret rieve $\& \mathrm{db}=$ PubMed\&dopt $=$ Citation\&list_uids $=15101101$

143.Masuda, T., Y. Inaba, T. Maekawa, Y. Takeda, H. Yamaguchi, K. Nakamoto, H. Kuninaga, S. Nishizato and A. Nonaka, 2003. Simple detection method of powerful antiradical compounds in the raw extract of plants and its application for the identification of antiradical plant constituents. J. Agric. Food Chem., 51: 1831-1838. DOI: 10.1021/jf026112m

144.Jung, K., Y.W. Chin, Y.C. Kim and J. Kim, 2005. Potentially hepatoprotective glycolipid constituents of Lycium chinense fruits. Arch. Pharm. Res., 28: 1381-1385. http://www.ncbi.nlm.nih.gov/entrez/query.fcgi?cm $\mathrm{d}=$ Retrieve\& $\mathrm{db}=$ PubMed\&dopt $=$ Citation\&list_uids $=16392672$
145.Lin, R.D., W.C. Hou, K.Y. Yen and M.H. Lee, 2003. Inhibition of monoamine oxidase B (MAOB) by Chinese herbal medicines. Phytomedicine, 10: 650-656.

http://www.ncbi.nlm.nih.gov/entrez/query.fcgi?cmd=Ret rieve $\& \mathrm{db}=$ PubMed $\&$ dopt $=$ Citation\&list_uids $=14692725$

146.Azuma, K., A. Ohyama, K. Ippoushi, T. Ichiyanagi, A. Takeuchi, T. Saito and H. Fukuoka, 2008. Structures and antioxidant activity of anthocyanins in many accessions of eggplant and its related species. J. Agric. Food Chem., 56: 10154-10159. DOI: $10.1021 / \mathrm{jf} 801322 \mathrm{~m}$

147.Liu, Z.L., Y.L. Zhu, C.M. Hu, G.P. Wei, L.F. Yang and G.W. Zhang, 2007. [Effects of $\mathrm{NaCl}$ stress on the growth, antioxidant enzyme activities and reactive oxygen metabolism of grafted eggplant]. Ying Yong Sheng Tai Xue Bao, 18: 537-41. http://www.ncbi.nlm.nih.gov/entrez/query.fcgi?cmd=Ret rieve $\& d b=$ PubMed $\&$ dopt $=$ Citation\&list_uids $=17552189$

148. Matsubara, K., T. Kaneyuki, T. Miyake and M. Mori, 2005. Antiangiogenic activity of nasunin, an antioxidant anthocyanin, in eggplant peels. J. Agric. Food Chem., 53: 6272-6275. DOI: 10.1021/jf050796r

149.Han, S.W., J. Tae, J.A. Kim, D.K. Kim, G.S. Seo, K.J. Yun, S.C. Choi, T.H. Kim, Y.H. Nah and Y.M. Lee, 2003. The aqueous extract of Solanum melongena inhibits PAR2 agonist-induced inflammation. Clin. Chim. Acta, 328: 39-44. http://www.ncbi.nlm.nih.gov/entrez/query.fcgi? $\mathrm{cmd}=$ Ret rieve $\& \mathrm{db}=$ PubMed\&dopt $=$ Citation\&list_uids $=12559597$

150.Chong, T.M., M.A. Abdullah, N.M. Fadzillah, O.M. Lai and N.H. Lajis, 2004. Anthraquinones production, hydrogen peroxide level and antioxidant vitamins in Morinda elliptica cell suspension cultures from intermediary and production medium strategies. Plant Cell Rep., 22: 951-958. DOI: 10.1007/s00299-004-0793-z

151.Takayama, H., I. Mori, M. Kitajima, N. Aimi and N.H. Lajis, 2004. New type of trimeric and pentameric indole alkaloids from Psychotria rostrata. Org. Lett., 6: 2945-2948. DOI: 10.1021/ol048971x

152.Matsuda, Y., M. Kitajima and H. Takayama, 2008. First total synthesis of trimeric indole alkaloid, psychotrimine. Org. Lett., 10: 125-128. DOI: $10.1021 / \mathrm{ol} 702637 \mathrm{r}$

153.Rukachaisirikul, T., P. Siriwattanakit, K. Sukcharoenphol, C. Wongvein, P. Ruttanaweang, P. Wongwattanavuch and A. Suksamrarn, 2004. Chemical constituents and bioactivity of Piper sarmentosum. J. Ethnopharmacol., 93: 173-176. DOI: $10.1016 /$ j.jep.2004.01.022 
154.Habsah, M., M. Amran, M.M. Mackeen, N.H. Lajis, H. Kikuzaki, N. Nakatani, A.A. Rahman, Ghafar and A.M. Ali, 2000. Screening of Zingiberaceae extracts for antimicrobial and antioxidant activities. J. Ethnopharmacol., 72: 403-410. http:/www.ncbi.nlm.nih.gov/entrez/query.fcgi?cm $\mathrm{d}=$ Retrieve\& $\mathrm{db}=$ PubMed\&dopt $=$ Citation\&list_uids $=10996279$

155.Mohamad, H., Abas. F., D. Permana, N.H. Lajis, A.M. Ali, M.A. Sukari, T.Y. Hin, H. Kikuzaki and N. Nakatani, 2004. DPPH free radical scavenger components from the fruits of Alpinia rafflesiana Wall. ex. Bak. (Zingiberaceae). Z. Naturforsch [C]. 59: 811-815. DOI: 10.1021/np0400981
156.Abas, F., L.S. Hui, S. Ahmad, J. Stanslas, D.A. Israf, K. Shaari and N.H. Lajis, 2006. Biological evaluation of curcumin and related diarylheptanoids. Z Naturforsch [C]. 61: 625-631. http://www.ncbi.nlm.nih.gov/entrez/query.fcgi?cmd=Ret rieve $\& \mathrm{db}=$ PubMed $\&$ dopt $=$ Citation $\&$ list uids $=17137104$

157.Abas, F., N.H. Lajis, K. Shaari, D.A. Israf, J. Stanslas, U.K. Yusuf and S.M. Raof, 2005. A labdane diterpene glucoside from the rhizomes of Curcuma mangga. J. Nat. Prod., 68: 1090-1093. DOI: $10.1021 / \mathrm{np} 0500171$

158. Tewtrakul, S. and S. Subhadhirasakul, 2007. Antiallergic activity of some selected plants in the Zingiberaceae family. J. Ethnopharmacol., 109: 535-538. DOI: 10.1016/j.jep.2006.08.010 